\title{
Do fluoroquinolone agents produce therapeutic benefits or harmful effects in patients with periodontitis? A systematic review and meta-analysis
}

\author{
Saray Aranda Romo ${ }^{1, A-C, E, F}$, Flavio Martinez-Morales ${ }^{2, B, C, E, F}$, Othoniel Hugo Aragon-Martinez ${ }^{2, A-D, F}$ \\ ${ }^{1}$ Periodontics Postgraduate Program, School of Dentistry, Autonomous University of San Luis Potosí, Mexico \\ ${ }^{2}$ Department of Pharmacology, School of Medicine, Autonomous University of San Luis Potosí, Mexico \\ A - research concept and design; $\mathrm{B}$ - collection and/or assembly of data; $\mathrm{C}$ - data analysis and interpretation; \\ $D$ - writing the article; $E$ - critical revision of the article; $F$ - final approval of the article
}

Address for correspondence

Othoniel Hugo Aragon-Martinez

E-mail: hugo.aragon@uaslp.mx

Funding sources

None declared

Conflict of interest

None declared

Acknowledgements

This work was supported by the Fund for Supporting

Research (Fondo de Apoyo a la Investigación - FAl)

of the Autonomous University of San Luis Potosí, Mexico (grant No. (19-FAl-05-54.54).

Received on 0ctober 31, 2020

Reviewed on February 9, 2021

Accepted on February 20, 2021

Published online on June 25, 2021

Cite as

Aranda Romo S, Martinez-Morales F, Aragon-Martinez OH. Do fluoroquinolone agents produce therapeutic benefits or harmful effects in patients with periodontitis? A systematic review and meta-analysis. Dent Med Probl. 2021;58(2):253-266 doi:10.17219/dmp/133512

DOI

$10.17219 / \mathrm{dmp} / 133512$

Copyright

( 2021 by Wroclaw Medical University

This is an article distributed under the terms of the

Creative Commons Attribution 3.0 Unported License (CC BY 3.0)

(https://creativecommons.org/licenses/by/3.0/).

\begin{abstract}
The adjunctive use of fluoroquinolone (FQ) agents in patients with periodontitis produces contradictory results. There has been no meta-analysis performed based on the evaluations of FQ use that would enable making appropriate clinical decisions. Our study aimed to evaluate, via a systematic review and metaanalysis conducted in accordance with the PRISMA (Preferred Reporting Items for Systematic reviews and Meta-Analyses) guidelines, the clinical benefits, antimicrobial effects and safety profiles of the FQ agents administered to periodontitis patients under a conventional treatment regime. Relevant databases were searched for studies published up to May 2020, with the quality and risk of bias evaluations performed on the selected studies, and meta-analyses, funnel plots and heterogeneity tests carried out based on the obtained data. Any finding of $p$-value less than 0.05 was considered statistically significant. Quality and the risk of bias ranged from high to low. With acceptable heterogeneity and no reporting bias, the meta-analyses showed that local or systemic FQ use produced the following results: a reduced probing depth change $(\triangle P D)$ ( $p<0.00001$ at $\leq 3$ months); reduced bleeding on probing (\%BOP) $(p<0.00001$ at 3-6 months); reduced subgingival detection of Aggregatibacter actinomycetemcomitans for up to 12 months ( $p$-values from $<0.00001$ to 0.001 ); and an insignificant number of adverse events $(p \geq 0.05)$ in patients subjected to a conventional therapy as compared to those subjected to an antibiotic-free therapy. Our study found evidence to show that $\mathrm{FQ}$ administration provides clinical benefits and ensures antibacterial effects in periodontitis patients subjected to a conventional therapy regime.
\end{abstract}

Keywords: periodontitis, meta-analysis, fluoroquinolone, adjunctive therapy 


\section{Introduction}

It is well known that dental plaque can initiate gingival inflammation (gingivitis), which, in many cases, can progress, leading to the destruction of the underlying connective tissue and the alveolar bone (periodontitis), resulting in the loss of the affected tooth. ${ }^{1}$ Periodontitis is one of the most predominant oral diseases; it affects the majority of the global population. ${ }^{2}$ Variability in the individual host's response to local factors plays a crucial role in this condition, and the loss of balance between the host's response and the oral microbiome leads to development and progression of the disease. ${ }^{1}$ Aggregatibacter actinomycetemcomitans (A. actinomycetemcomitans) and members of the red complex (e.g., Porphyromonas gingivalis - P. gingivalis, Tannerella forsythia - T. forsythia and Treponema denticola - T. denticola) are the most significant species associated with periodontitis. ${ }^{3}$ During the course of this disease, the foregoing bacteria penetrate the tissues and the periodontium, triggering the host's immune response to the invading bacteria. ${ }^{4}$ Periodontitis has also been associated with the presence of various systemic disorders, such as coronary heart disease, diabetes, cerebrovascular disease, and pancreatic cancer. ${ }^{5,6}$

The conventional treatment of periodontitis involves an oral hygiene program administered at home, and professional management (e.g., scaling) conducted via surgical or nonsurgical access to the affected sites. This kind of treatment is effective for the majority of patients and is followed by a recall program, which provides periodontal care every $3-4$ months and helps to prevent the progression of the disease to a chronic state. However, the use of adjunctive treatment is necessary in the case of patients for whom the recall program has been unsuccessful. Adjunctive therapies comprise the local or systemic administration of antimicrobials, $^{7}$ of which fluoroquinolone (FQ) agents are one of the most important antibiotics prescribed by oral healthcare professionals. ${ }^{8,9}$ Fluoroquinolone agents, a family of broad-spectrum antibacterial agents acting against a wide range of aerobic grampositive and gram-negative organisms, ${ }^{10}$ act by binding to an intracellular target in the cytosol of bacteria, where they inhibit the activity of DNA gyrase, with a high selectivity for prokaryotic enzymes. ${ }^{11,12}$

While numerous studies have evaluated the clinical and microbiological efficacy as well as the safety profiles of FQ agents in patients with periodontitis, ${ }^{3,13-26}$ the results are often contradictory. A precise clinical evaluation requires the use of statistical methods, such as meta-analysis, to combine the results obtained through independent studies. Meta-analysis provides a more exact estimate of the health effects of treatment than those derived from individual studies. ${ }^{27}$
To date, there have been no review and meta-analysis carried out to evaluate the efficacy and safety profiles of the FQ agents used as adjuncts to the conventional treatment of periodontitis patients. Therefore, the aim of our study was to evaluate, using the systematic review and meta-analysis methodology, the clinical, antimicrobial and harmful effects of the FQ agents administered in combination with conventional treatment for periodontitis.

\section{Methods}

\section{Search strategy}

The present study was conducted in accordance with the PRISMA (Preferred Reporting Items for Systematic reviews and Meta-Analyses) guidelines. ${ }^{28,29}$ In addition, the protocol for the systematic review portion of the present study was registered in the International Prospective Register of Systematic Reviews (PROSPERO) of the United Kingdom's National Institute for Health Research (NIHR).

The PubMed, MEDLINE, Cochrane, LILACS, and Imbiomed databases were searched from their earliest records to May 31, 2020 to identify interventional studies that employed FQ agents for the adjunctive treatment of periodontitis. The following search terms were used for the PubMed, MEDLINE, Cochrane, and LILACS databases: "chronic periodontitis" AND "fluoroquinolone"; "chronic periodontitis" AND "levofloxacin"; "chronic periodontitis" AND "moxifloxacin"; "chronic periodontitis" AND "ciprofloxacin"; "chronic periodontitis" AND "ofloxacin"; "chronic periodontitis" AND "sitafloxacin"; "chronic periodontitis" AND "sparfloxacin"; "aggressive periodontitis" AND "fluoroquinolone"; "aggressive periodontitis" AND "levofloxacin"; "aggressive periodontitis" AND "moxifloxacin"; "aggressive periodontitis" AND "ciprofloxacin"; "aggressive periodontitis" AND "ofloxacin"; "aggressive periodontitis" AND "sitafloxacin"; "aggressive periodontitis" AND "sparfloxacin"; "periodontitis" AND "fluoroquinolone"; "periodontitis" AND "levofloxacin"; "periodontitis" AND "moxifloxacin"; "periodontitis" AND "ciprofloxacin"; "periodontitis" AND "ofloxacin"; "periodontitis" AND "sitafloxacin"; and "periodontitis" AND "sparfloxacin". In this manner, 21 combinations of 2 different terms were used for each database. Due to the nature of the platform, the following single search terms were used for the Imbiomed database: levofloxacin (LVX); moxifloxacin (MOX); ciprofloxacin (CPX); ofloxacin (OFX); sitafloxacin (STX); sparfloxacin (SPX); fluoroquinolone; chronic periodontitis; aggressive periodontitis; and periodontitis. 


\section{Eligibility criteria}

Research papers were selected based on the following inclusion criteria: a randomized or non-randomized controlled clinical trial that employed a parallel or split-mouth design to systemically treat healthy patients diagnosed with chronic, adult or aggressive periodontitis; at least 1 test group received an FQ agent; the report was published in English or Spanish. The exclusions criteria were as follows: an FQ agent was not administered as an adjunctive therapy; an antibiotic-free group was not included in the study; the study participants had been prescribed an antiinflammatory medication; the patients had taken an antibiotic in the previous 3 months; all the data used in the study had been taken from another study by the same author. This last criterion did not include duplicates, as those studies were not the exact copies of each other.

\section{Data extraction}

First, 2 researchers independently screened the titles and abstracts of the articles found, and then reviewed full-text papers. Once the initial evaluation was completed, a third researcher reviewed the work. Any discrepancy between the evaluations was resolved by consensus with the input of another experienced researcher. The following characteristics were extracted from each study: first author; year of publication; the participants' age; study design; confirmed diagnosis of the disease; number of patients; intervention characteristics (active principle, concentration, dose interval, and route of administration); periodontal parameters; adverse effects; and number of patients in whom periodontitis-related microorganisms had been identified via subgingival detection. The periodontal parameters used were probing depth (PD), clinical attachment level $(\mathrm{CAL}), \mathrm{PD}$ change $(\triangle \mathrm{PD})$, gain of $\mathrm{CAL}$ $(\triangle \mathrm{CAL})$, percentage of sites with bleeding on probing (\%BOP), plaque index (PI), and gingival index (GI). When a study featured more than 1 group treated with the same FQ agent, but at a different concentration, the information was harvested solely from the test group which received the dose with the most beneficial effects. The extracted information was grouped into the following periods of time: $\leq 3$ months post-intervention; $>3$ and $\leq 6$ months post-intervention; and $>6$ and $\leq 12$ months post-intervention. When a study involved 2 or more examinations in an established timeframe, the information was collected solely from the examination with the longest timeframe.

\section{Assessment of quality and the risk of bias}

The quality of the selected studies was assessed using the Oxford Quality Scale, ${ }^{30}$ as described previously. ${ }^{31-33}$ Clinical trials with scores $\geq 3$ were classified as high-quality studies, while those with scores $<3$ were considered low-quality studies. The internal validity of the selected studies was evaluated using the Cochrane Collaboration's risk of bias (RoB) tool. ${ }^{34}$ This tool uses the following criteria to assess the risk of bias: random sequence generation, allocation concealment, blinding of participants and personnel, blinding of outcome assessment, incomplete outcome data, selective reporting, and other bias. According to the procedure described by Higgins et al., each criterion was categorized as a low, unclear or high risk of bias, ${ }^{35}$ with a risk of bias graph used to show the proportion of the selected studies falling into each category. Each quality and risk of bias assessment was reviewed by an additional researcher, with any discrepancies resolved as described above.

\section{Data analysis}

The meta-analyses were performed based on the data obtained from studies of periodontitis patients treated with an adjunctive control or FQ intervention, administered either locally or systemically. For continuous data, each meta-analysis was carried out with the use of the inverse variance (IV) method. The mean differences (or standardized mean differences) and their 95\% confidence intervals ( $C I$ s) were analyzed with the fixed effects model, using the Review Manager 5.3 software. ${ }^{34}$ For dichotomous data, the meta-analyses were performed with the Mantel-Haenszel ( $\mathrm{MH}$ ) method. The odds ratios (ORs) (or risk differences) and their 95\% CIs were analyzed with the fixed effects model, using the software mentioned above, and statistic $Z$, statistic $I^{2}$ and $p$-values were used to evaluate the overall effect, heterogeneity and probability, respectively. Statistic $I^{2}$ ranging from 0 to $40 \%$, from 40 to $70 \%$, or from 70 to $100 \%$ was considered as absent, acceptable or considerable heterogeneity, respectively, with probability of less than 0.05 accepted as significant. With a funnel plot used to detect reporting bias in each conducted meta-analysis, the presence of any reporting bias produced an asymmetrical funnel. ${ }^{36}$

\section{Results}

\section{Characteristics and evaluation of the studies}

Thirty-one studies were identified as complying with the selection criterion of using an adjunctive FQ agent to treat patients with periodontitis (Fig. 1). Of these studies, 19 were excluded: 1 did not employ an FQ insert as an adjunctive therapy, ${ }^{25} 14$ did not include a comparator group without an antibiotic, ${ }^{9,21,37-48}$ 
3 studies used the data extracted from a study by the same author that had already been considered in the present study, ${ }^{13,15,49}$ and 1 other study used ibuprofen together with MOX. ${ }^{50}$ The characteristics and outcomes of the studies selected for analysis are summarized in Table 1 and Table 2. A dose of $0.4 \%$ MOX was selected for our review, as Flemmig et al. claimed that this dose produced better results than other doses. ${ }^{19}$ The studies conducted by Ardila et al., ${ }^{14}$ Pradeep et al., ${ }^{3}$ Pradeep et al., ${ }^{17}$ Flemmig et al., ${ }^{19}$ Khan et al., ${ }^{16}$ Nakajima et al., ${ }^{18}$ Guentsch et al., ${ }^{20}$ Kimura et al., ${ }^{26}$ Tezel et al., ${ }^{51}$ Kleinfelder et al., ${ }^{23}$ Parthasarathy et al., ${ }^{22}$ and Nagaraju et al. ${ }^{24}$ received quality scores of $5,5,5$, $5,3,3,3,3,2,2,1$, and 1 , respectively.

Our quantitative analysis did not include the studies by Parthasarathy et al. ${ }^{22}$ and Kimura et al., ${ }^{26}$ as the former used incomplete data (means without standard deviations) and the latter solely reported undetectable subgingival levels of $A$. actinomycetemcomitans in patients during the entire course of the therapeutic intervention. Furthermore, some of the information from the studies included in the present review could not be extracted, as it was presented solely in the graphic form (e.g., the PD, CAL, \%BOP, and GI values presented by Khan et al. $\left.{ }^{16}\right)$. Since 2 studies by the same author, ${ }^{3,17}$ which were included in the present study, were conducted in the same place and period of time, the data extraction procedure was performed in such a way as to avoid redundancy. Figure 2 shows the risk of bias for the 10 studies subjected to the quantitative analysis presented below.

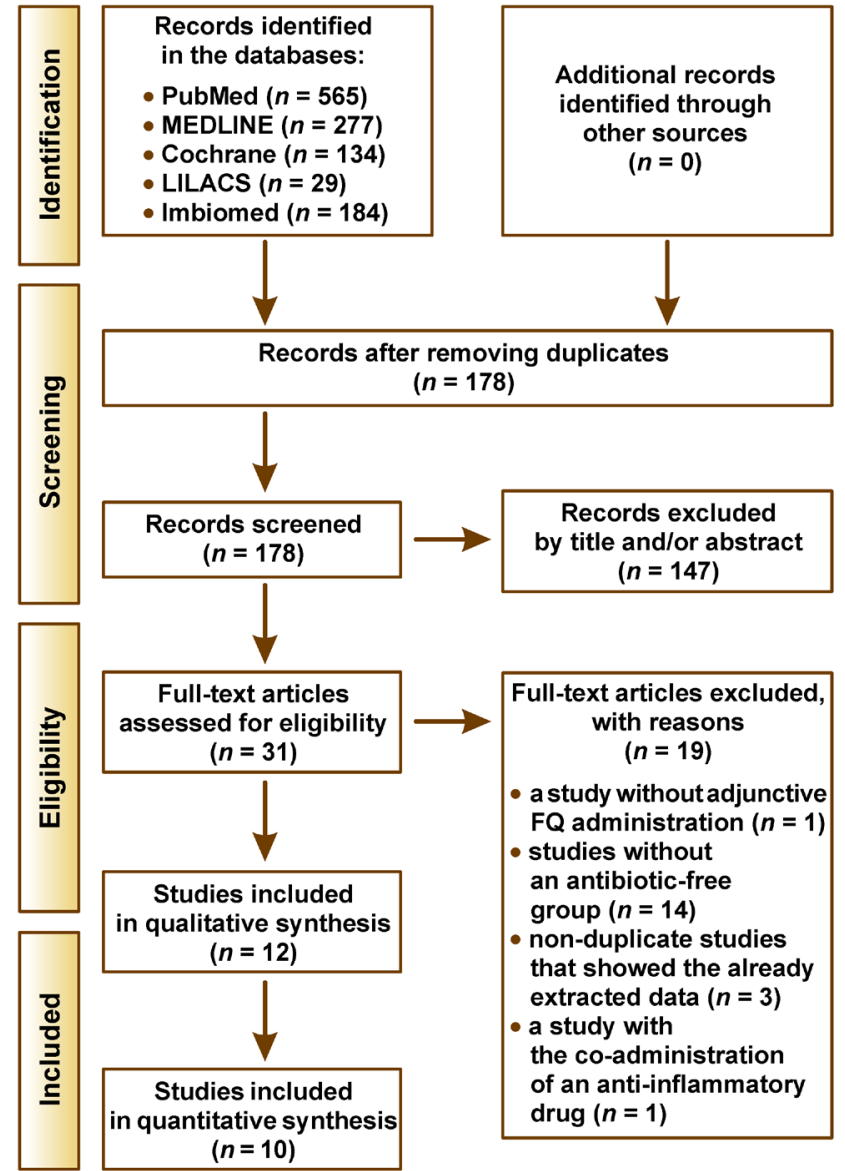

Fig. 1. Search strategy - PRISMA (Preferred Reporting Items for Systematic reviews and Meta-Analyses) flow diagram

$\mathrm{FQ}$ - fluoroquinolone.

Table 1. Characteristics of the included studies

\begin{tabular}{|c|c|c|c|c|}
\hline $\begin{array}{l}\text { First author, } \\
\text { year } \\
\text { of publication }\end{array}$ & $\begin{array}{c}\text { Study design, } \\
\text { diagnosis of disease }\end{array}$ & $\begin{array}{l}\text { Groups (sample size) } \\
\text { and } \\
\text { the participants'age }\end{array}$ & Intervention characteristics & $\begin{array}{l}\text { Clinical and/or } \\
\text { bacteriological } \\
\text { measurements }\end{array}$ \\
\hline $\begin{array}{l}\text { Kimura et al. } \\
1991^{26}\end{array}$ & $\begin{array}{l}\text { - design: randomized, } \\
\text { placebo-controlled, } \\
\text { split-mouth clinical } \\
\text { study } \\
\text { - disease: chronic } \\
\text { periodontitis }\end{array}$ & $\begin{array}{l}\text { - groups: } \\
\text { - test group: SRP + OFX } \\
(n=27) \\
\text { - control group: SRP } \\
\text { + placebo }(n=27) \\
\text { - mean age of the } \\
\text { participants: } 43.9 \text { years }\end{array}$ & $\begin{array}{l}\text { - Each insert was } 1 \mathrm{~mm} \text { wide and } 0.4 \mathrm{~mm} \text { thick. The test insert } \\
\text { contained OFX } 10 \% \mathrm{w} / \mathrm{w} \text { ( } 40 \mathrm{\mu g} / \mathrm{mm} \text { of the film length). } \\
\text { - The patients received instructions for appropriate oral hygiene. } \\
\text { - Before the baseline visit, STC was carried out and inserts were } \\
\text { placed into pockets on a weekly basis for } 2 \text { weeks. The test and } \\
\text { control inserts were applied in different pockets of the same } \\
\text { patient. } \\
\text { - During the baseline visit, the SRP intervention and the } \\
\text { application of inserts were carried out. } \\
\text { - After the baseline visit, the test and placebo inserts were } \\
\text { applied on a weekly basis for } 3 \text { weeks. }\end{array}$ & $\begin{array}{l}\text { - } 2 \text { weeks before } \\
\text { the baseline } \\
\text { visit } \\
\text { - during the } \\
\text { baseline visit } \\
\text { - } 1 \text { and } 4 \text { weeks } \\
\text { after the } \\
\text { baseline visit }\end{array}$ \\
\hline $\begin{array}{l}\text { Nagaraju et al. } \\
1999^{24}\end{array}$ & $\begin{array}{l}\text { - design: placebo- } \\
\text { controlled, split- } \\
\text { mouth clinical study } \\
\text { - disease: chronic } \\
\text { periodontitis }\end{array}$ & $\begin{array}{l}\text { - groups: } \\
\text { - test group: STC + CPX } \\
\text { implant ( } n=10) \\
\text { - control group: STC } \\
\text { + placebo implant }(n=10) \\
\text { - age of the participants: } \\
\text { not provided }\end{array}$ & $\begin{array}{l}\text { - Each drug implant contained } 1 \mathrm{mg} C P X \text { and was cut to a } \\
0.5 \mathrm{~cm} \times 0.5 \mathrm{~cm} \text { size. } \\
\text { - The patients received instructions for appropriate oral hygiene. } \\
\text { - After the removal of supragingival surface deposits, the test } \\
\text { and placebo implants were placed in different pockets of the } \\
\text { same patient without sutures or dressing. }\end{array}$ & $\begin{array}{l}\text { - before the } \\
\text { implant } \\
\text { application } \\
\text { - 10, 20,30, and } \\
40 \text { days after } \\
\text { the implant } \\
\text { application }\end{array}$ \\
\hline $\begin{array}{l}\text { Kleinfelder et al. } \\
2000^{23}\end{array}$ & $\begin{array}{l}\text { - design: controlled, } \\
\text { single-blinded, } \\
\text { parallel-arm clinical } \\
\text { trial } \\
\text { - disease: Aa-associated } \\
\text { adult periodontitis }\end{array}$ & $\begin{array}{l}\text { - groups: } \\
\text { - test group: flap surgery } \\
\text { + STC and OFX ( } n=22 ; \\
\text { mean age: } 47.7 \text { years) } \\
\text { • control group: flap } \\
\text { surgery + STC ( } n=10 ; \\
\text { mean age: } 46 \text { years) }\end{array}$ & $\begin{array}{l}\text { - Before the surgical therapy, the patients received an STC } \\
\text { intervention and instructions for appropriate oral hygiene. } \\
\text { - An open flap debridement was conducted on the pockets of } \\
\text { patients with PD } \geq 5 \text { mm. Full-mouth surgery was performed } \\
\text { within } 3 \text { or } 4 \text { appointments, and was completed after } 2 \text { or } 3 \\
\text { weeks. In addition, the patients belonging to the test group } \\
\text { received the systemic application of } 400 \text { mg OFX once a day } \\
\text { for } 5 \text { days, starting from the } 1^{\text {st }} \text { day of flap surgery. } \\
\text { - After the surgical therapy, the patients received STC every } 3 \text { months. }\end{array}$ & $\begin{array}{l}\text { - before the } \\
\text { surgical } \\
\text { therapy } \\
\text { - } 3 \text { and } \\
12 \text { months } \\
\text { after the flap } \\
\text { surgery }\end{array}$ \\
\hline
\end{tabular}




\begin{tabular}{|c|c|c|c|c|}
\hline $\begin{array}{l}\text { First author, } \\
\text { year } \\
\text { of publication }\end{array}$ & $\begin{array}{l}\text { Study design, } \\
\text { diagnosis of disease }\end{array}$ & $\begin{array}{l}\text { Groups (sample size) } \\
\text { and } \\
\text { the participants' age }\end{array}$ & Intervention characteristics & $\begin{array}{l}\text { Clinical and/or } \\
\text { bacteriological } \\
\text { measurements }\end{array}$ \\
\hline $\begin{array}{l}\text { Parthasarathy et al. } \\
2002^{22}\end{array}$ & $\begin{array}{l}\text { - design: placebo- } \\
\text { controlled, split- } \\
\text { mouth clinical study } \\
\text { - disease: severe chronic } \\
\text { periodontitis }\end{array}$ & $\begin{array}{l}\text { - groups: } \\
\text { - test group: STC + SPX } \\
\text { chip ( } n=10) \\
\text { - control group: STC } \\
\text { + placebo chip }(n=10) \\
\text { - age of the participants: } \\
\text { not provided }\end{array}$ & $\begin{array}{l}\text { - Each chip was } 10 \mathrm{~mm} \text { long, } 2 \mathrm{~mm} \text { wide and } 0.5 \mathrm{~mm} \text { thick. The } \\
\text { drug chip contained } 2 \mathrm{mg} \text { SPX. } \\
\text { - Before the implantation of chips, the patients underwent an } \\
\text { STC session. } \\
\text { - Both the test and placebo chips were inserted into different } \\
\text { pockets of the same patient and kept in place with a } \\
\text { periodontal dressing. } \\
\text { - Twenty-one days post-implantation, each chip was removed } \\
\text { from the periodontal pocket. }\end{array}$ & $\begin{array}{l}\text { - before the } \\
\text { implantation } \\
-1,7,14 \text {, and } \\
21 \text { days } \\
\text { after the } \\
\text { implantation }\end{array}$ \\
\hline $\begin{array}{l}\text { Tezel et al. } \\
2005^{51}\end{array}$ & $\begin{array}{l}\text { - design: single-blinded, } \\
\text { parallel-arm clinical } \\
\text { study } \\
\text { - disease: chronic } \\
\text { periodontitis }\end{array}$ & $\begin{array}{l}\text { - groups: } \\
\text { - test group: SRP + CPX } \\
(n=8) \\
\text { - control group: SRP alone } \\
(n=8) \\
\text { - mean age of the } \\
\text { participants: } 39.2 \text { years }\end{array}$ & $\begin{array}{l}\text { - Before the intervention, the patients were instructed to apply } \\
\text { solely manual toothbrushing and to use dental floss for the } \\
\text { duration of the study. } \\
\text { - The intervention comprised full-mouth SRP, with the patients } \\
\text { belonging to the test group receiving systemic } 500 \text { mg CPX } \\
\text { once a day for } 7 \text { days. }\end{array}$ & $\begin{array}{l}\text { - before the } \\
\text { intervention } \\
-7,21 \text { and } \\
90 \text { days } \\
\text { after the } \\
\text { intervention }\end{array}$ \\
\hline $\begin{array}{l}\text { Guentsch et al. } \\
2008^{20}\end{array}$ & $\begin{array}{l}\text { - design: randomized, } \\
\text { controlled, single- } \\
\text { blinded, parallel-arm } \\
\text { clinical trial } \\
\text { - disease: severe chronic } \\
\text { periodontitis }\end{array}$ & $\begin{array}{l}\text { - groups: } \\
\text { - test group: SRP + MOX } \\
(n=35) \\
\text { - control group: SRP } \\
\text { + placebo }(n=21) \\
\text { - mean age of the } \\
\text { participants: } 49.6 \text { years }\end{array}$ & $\begin{array}{l}\text { - Before the treatment, the patients received instructions for } \\
\text { appropriate oral hygiene. } \\
\text { - The treatment consisted of rinsing with chlorhexidine, one- } \\
\text { stage full-mouth SRP, and the daily administration of the test } \\
\text { or placebo tablet for } 7 \text { days. The drug tablet contained } 400 \text { mg } \\
\text { MOX. Some patients belonging to the control group did not } \\
\text { receive the placebo tablet. }\end{array}$ & $\begin{array}{l}\text { - } 1 \text { week before } \\
\text { the treatment } \\
-3,6 \text { and } \\
12 \text { months } \\
\text { after the } \\
\text { treatment }\end{array}$ \\
\hline $\begin{array}{l}\text { Flem } \\
2011\end{array}$ & $\begin{array}{l}\text { - design: randomized, } \\
\text { placebo-controlled, } \\
\text { double-blinded, } \\
\text { parallel-arm clinical trial } \\
\text { - disease: chronic } \\
\text { periodontitis }\end{array}$ & $\begin{array}{l}\text { - groups: } \\
\text { - test group: SRP + MOX } \\
\text { ( } n=15 ; \text { mean age: } \\
47.7 \text { years) } \\
\text { - control group: SRP } \\
\text { + placebo ( } n=15 ; \text { mean } \\
\text { age: } 46 \text { years) }\end{array}$ & $\begin{array}{l}\text { - Before the application of gel, full-mouth SRP was performed in } \\
\text { the patients on } 2 \text { consecutive days. } \\
\text { - A single dose of } 0.4 \% \text { MOX or placebo gel was placed in the } \\
\text { periodontal pocket of the tooth. Gel was applied until the } \\
\text { pocket overflowed with excess gel. } \\
\text { - After the application of gel, the patients performed routine oral } \\
\text { hygiene and used amine fluoride dentifrice. }\end{array}$ & $\begin{array}{l}- \text { before SRP } \\
-6 \text { weeks and } \\
3 \text { months } \\
\text { after the gel } \\
\text { application }\end{array}$ \\
\hline $\begin{array}{l}\text { Nakajima et al. } \\
2012^{18}\end{array}$ & $\begin{array}{l}\text { - design: randomized, } \\
\text { controlled, single- } \\
\text { blinded, parallel-arm } \\
\text { clinical trial } \\
\text { - disease: chronic } \\
\text { periodontitis }\end{array}$ & $\begin{array}{l}\text { - groups: } \\
\text { - test group: STC + STX } \\
\text { ( } n=20 ; \text { mean age: } \\
\text { 60.7 years) } \\
\text { - control group: STC + SRP } \\
\text { ( } n=19 ; \text { mean age: } \\
63.4 \text { years) }\end{array}$ & $\begin{array}{l}\text { - During the baseline visit, the patients received an STC } \\
\text { intervention and instructions for appropriate oral hygiene. } \\
\text { In addition, the patients belonging to the test group were } \\
\text { orally administered } 50 \text { mg STX twice a day for } 5 \text { days, whereas } \\
\text { the patients belonging to the control group received an SRP } \\
\text { intervention. } \\
\text { - The patients received STC } 1 \text { and } 3 \text { months after the baseline visit. }\end{array}$ & $\begin{array}{l}\text { - during the } \\
\text { baseline visit } \\
\text { - } 1 \text { and } \\
3 \text { months after } \\
\text { the baseline } \\
\text { visit }\end{array}$ \\
\hline $\begin{array}{l}\text { Pradeep et al. } \\
2014^{17}\end{array}$ & $\begin{array}{l}\text { - design: randomized, } \\
\text { placebo-controlled, } \\
\text { double-blinded, } \\
\text { parallel-arm clinical trial } \\
\text { - disease: Aa-associated } \\
\text { chronic periodontitis }\end{array}$ & $\begin{array}{l}\text { - groups: } \\
\text { - test group: SRP + LVX } \\
\text { ( } n=34 ; \text { mean age: } \\
36.7 \text { years) } \\
\text { - control group: SRP } \\
\text { + placebo ( } n=32 ; \text { mean } \\
\text { age: } 36.8 \text { years) }\end{array}$ & $\begin{array}{l}\text { - One week before the baseline visit, the patients received an } \\
\text { STC intervention and chlorhexidine rinse, and instructions for } \\
\text { appropriate oral hygiene. } \\
\text { - During the baseline visit, the patients underwent an SRP } \\
\text { session and the experimental therapy ( } 500 \text { mg LVX or the } \\
\text { placebo tablet once a day for } 10 \text { days). }\end{array}$ & $\begin{array}{l}\text { - during the } \\
\text { baseline visit } \\
\text { - } 10 \text { days, } \\
\text { and } 1,3 \text { and } \\
6 \text { months after } \\
\text { the baseline } \\
\text { visit }\end{array}$ \\
\hline $\begin{array}{l}\text { Pradeep et al. } \\
2015^{3}\end{array}$ & $\begin{array}{l}\text { - design: randomized, } \\
\text { placebo-controlled, } \\
\text { double-blinded, } \\
\text { parallel-arm } \\
\text { clinical trial } \\
\text { - disease: chronic } \\
\text { periodontitis }\end{array}$ & $\begin{array}{l}\text { - groups: } \\
\text { - test group: SRP + LVX } \\
\text { ( } n=33 ; \text { mean age: } \\
35.6 \text { years) } \\
\text { - control group: SRP } \\
\text { + placebo ( } n=32 ; \text { mean } \\
\text { age: } 35.9 \text { years) }\end{array}$ & The & $\begin{array}{l}\text { - during the } \\
\text { baseline visit } \\
\text { - } 10 \text { days, } \\
\text { and 1, } 3 \text { and } \\
6 \text { months after } \\
\text { the baseline } \\
\text { visit }\end{array}$ \\
\hline $\begin{array}{l}\text { Ardila et al. } \\
2015^{14}\end{array}$ & $\begin{array}{l}\text { - design: randomized, } \\
\text { placebo-controlled, } \\
\text { triple-blinded, parallel- } \\
\text { arm clinical trial } \\
\text { - disease: generalized } \\
\text { aggressive } \\
\text { periodontitis }\end{array}$ & $\begin{array}{l}\text { - groups: } \\
\text { - test group: SRP + MOX } \\
\text { ( } n=20 ; \text { mean age: } \\
28.4 \text { years) } \\
\text { - control group: SRP } \\
\text { + placebo ( } n=20 ; \text { mean } \\
\text { age: } 26.4 \text { years) }\end{array}$ & $\begin{array}{l}\text { - The patients received oral hygiene and home dental care } \\
\text { instructions during the course of the study. } \\
\text { - On the day of the intervention, the patients received one-stage } \\
\text { full-mouth SRP and the oral administration of the test ( } 400 \mathrm{mg} \\
\text { MOX) or placebo therapy. The capsule was taken once a day } \\
\text { for } 7 \text { days. }\end{array}$ & $\begin{array}{l}\text { - before SRP } \\
\text { - } 3 \text { and } 6 \text { months } \\
\text { after SRP }\end{array}$ \\
\hline $\begin{array}{l}\text { Khan et al. } \\
2016^{16}\end{array}$ & $\begin{array}{l}\text { - design: randomized, } \\
\text { placebo-controlled, } \\
\text { single-blinded, split- } \\
\text { mouth clinical study } \\
\text { - disease: chronic } \\
\text { periodontitis }\end{array}$ & $\begin{array}{l}\text { - groups: } \\
\text { - test group: SRP + LVX } \\
(n=10) \\
\text { - control group: SRP } \\
\text { + placebo }(n=10) \\
\text { - age of the participants: } \\
\text { 20-50 years }\end{array}$ & $\begin{array}{l}\text { - Each film weighed } 6.13 \pm 0.04 \mathrm{mg} \text {, with the drug film } \\
\text { containing a total LVX content of } 93.8 \pm 2.2 \% \text {. } \\
\text { - The patient's oral hygiene status was evaluated alongside the } \\
\text { clinical measurements. } \\
\text { - After a full-mouth SRP intervention, the test and placebo films } \\
\text { were inserted into different pockets of the same patient and } \\
\text { kept in place with a periodontal dressing, which was removed } \\
1 \text { week after the insertion of the film. }\end{array}$ & $\begin{array}{l}\text { - before the } \\
\text { intervention } \\
-1,2,4 \text {, and } \\
8 \text { weeks } \\
\text { after the } \\
\text { intervention }\end{array}$ \\
\hline
\end{tabular}

Aa - Aggregatibacter actinomycetemcomitans; SRP - scaling and root planing; OFX - ofloxacin; STC - supragingival tooth cleaning; CPX - ciprofloxacin; SPX - sparfloxacin; MOX - moxifloxacin; STX - sitafloxacin; LVX - levofloxacin; PD - probing depth. 
Table 2. Qualitative synthesis of the included studies

\begin{tabular}{|c|c|c|c|c|c|c|c|c|c|c|c|c|c|}
\hline \multirow[t]{2}{*}{$\begin{array}{c}\mathrm{FQ} \\
\text { agent }\end{array}$} & \multicolumn{7}{|c|}{$\begin{array}{c}\text { Was the periodontal parameter improved } \\
\text { due to an FQ intervention in comparison } \\
\text { with the control group? }\end{array}$} & \multicolumn{5}{|c|}{$\begin{array}{c}\text { Was the detection of the pathogen reduced } \\
\text { due to an FQ intervention in comparison } \\
\text { with the control data? }\end{array}$} & \multirow[t]{2}{*}{$\begin{array}{l}\text { Were any adverse } \\
\text { events reported } \\
\text { in the groups? }\end{array}$} \\
\hline & CAL & PD & $\triangle C A L$ & $\triangle \mathrm{PD}$ & $\%$ BOP & $\mathrm{Gl}$ & $\mathrm{PI}$ & $A a$ & $P g$ & Tf & $T d$ & Si & \\
\hline \multicolumn{14}{|c|}{ local administration } \\
\hline$C P X^{24}$ & - & - & yes $^{\mathrm{a}}$ & yes $^{\mathrm{a}}$ & - & yes $^{\mathrm{a}}$ & no ${ }^{a}$ & - & - & - & - & - & - \\
\hline $\operatorname{LVX}^{16}$ & no ${ }^{a}$ & $y_{e s}{ }^{a}$ & - & - & yes $^{\mathrm{a}, \mathrm{d}}$ & yes $^{\mathrm{a}}$ & - & - & - & - & - & - & none \\
\hline MOX $^{19}$ & - & - & no ${ }^{a}$ & $y_{e s}{ }^{a}$ & - & - & no ${ }^{\mathrm{a}}$ & no ${ }^{a}$ & $n o^{\mathrm{a}}$ & no ${ }^{\mathrm{a}}$ & $n o^{a}$ & no ${ }^{a}$ & yes (both groups) \\
\hline SPX 22 & - & - & - & - & yes $^{\mathrm{a}, \mathrm{d}}$ & - & yes $^{\mathrm{a}}$ & - & - & - & - & - & - \\
\hline OFX' & - & - & - & - & - & - & - & $\mathrm{ND}^{\mathrm{a}}$ & - & - & - & - & - \\
\hline \multicolumn{14}{|c|}{ systemic administration } \\
\hline$C P X^{51}$ & yes $^{\mathrm{a}}$ & - & - & - & - & $n o^{a}$ & no ${ }^{a}$ & - & - & - & - & - & - \\
\hline $\operatorname{LVX}^{3}$ & yes $^{a, b}$ & yes $^{\mathrm{a}, \mathrm{b}}$ & yes $^{a, b}$ & yes $^{a, b}$ & $n o^{a, b}$ & $n o^{a, b}$ & $n o^{a, b}$ & yes $^{\mathrm{a}, \mathrm{b}}$ & $n o^{a, b}$ & $n o^{a, b}$ & - & - & yes (FQ group) \\
\hline $\operatorname{LVX}^{17}$ & yes $^{\mathrm{a}, \mathrm{b}}$ & yes $^{\mathrm{a}, \mathrm{b}}$ & - & - & $n o^{a, b}$ & $n o^{a, b}$ & $n o^{a, b}$ & yes $^{\mathrm{a}, \mathrm{b}}$ & - & - & - & - & yes (FQ group) \\
\hline $\mathrm{MOX}^{14}$ & $y_{e s}^{a, b}$ & yes $^{a, b}$ & - & - & $n o^{a, b}$ & - & $n o^{a, b}$ & yes $^{a, b}$ & yes ${ }^{a, b}$ & $y_{e}^{a, b}$ & - & - & none \\
\hline $\mathrm{MOX}^{20}$ & $n o^{a, b, c}$ & $n o^{a, b, c}$ & $y_{e s}^{b, c}$ & yes $^{b, c}$ & $n o^{a, b, c}$ & - & - & yes $^{b}$ & $y_{e s}^{b}$ & $y_{e s}^{a, c}$ & $y_{e s}{ }^{a}$ & - & none \\
\hline $\mathrm{STX}^{18}$ & no ${ }^{a}$ & no ${ }^{a}$ & - & - & $n o^{a}$ & - & - & yes $^{\mathrm{a}}$ & no $o^{a}$ & $n o^{a}$ & $n o^{a}$ & - & yes (FQ group) \\
\hline $\mathrm{OFX}^{23}$ & yes $^{\mathrm{a}, \mathrm{c}}$ & $\mathrm{no}^{\mathrm{a}, \mathrm{c}}$ & - & - & $\mathrm{no}^{\mathrm{a}, \mathrm{c}}$ & - & - & yes $^{\mathrm{a}, \mathrm{c}}$ & - & - & - & - & - \\
\hline
\end{tabular}

a assessment at $\leq 3$ months post-intervention; ${ }^{b}$ assessment at $>3$ and $\leq 6$ months post-intervention; ${ }^{c}$ assessment at $>6$ and $\leq 12$ months post-intervention; ${ }^{\mathrm{d}}$ measurement performed as an index; $\mathrm{CAL}$ - clinical attachment level, $\triangle \mathrm{CAL}$ - gain of CAL; $\triangle \mathrm{PD}$ - PD change; \%BOP - percentage of sites with bleeding on probing; Gl - gingival index: PI - plaque index; Pg - Porphyromonas gingivalis; Tf - Tanerella forsythia; Td - Treponema denticola; Si - Streptococcus intermedius; ND - not detected in either group.

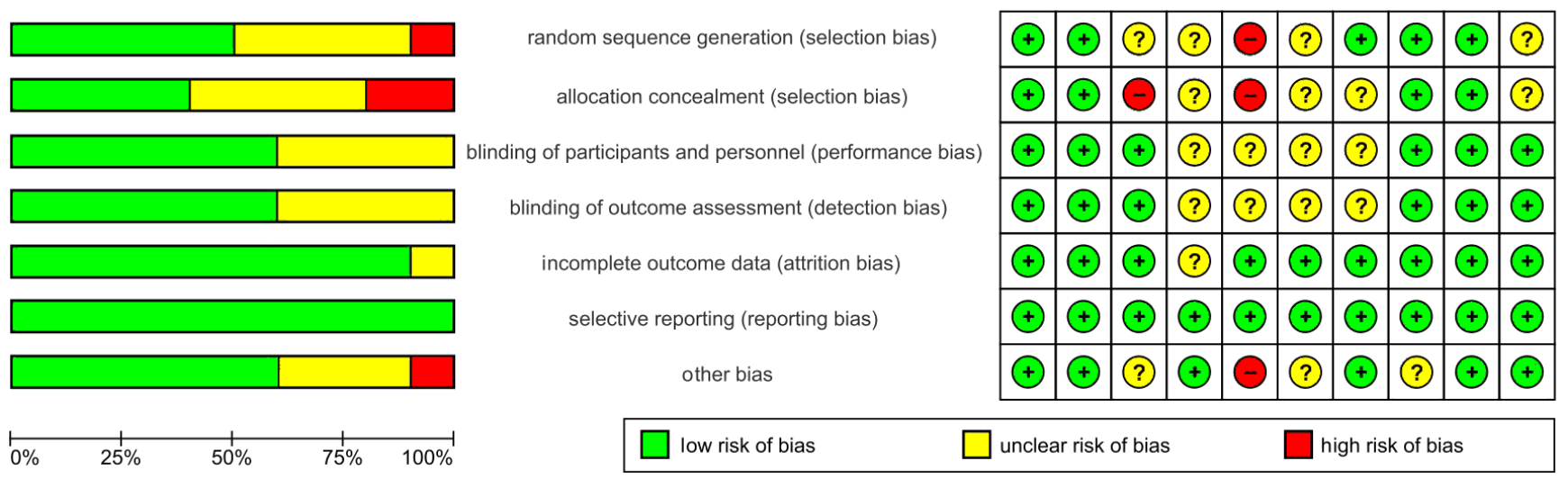

Fig. 2. Graph illustrating the risk of bias of the studies used for the meta-analyses

\section{Periodontal, bacteriological and safety examinations}

At $\leq 3$ months post-intervention, the $95 \%$ CI, Z-values and $p$-values obtained in the meta-analyses showed a reduction in $\triangle \mathrm{PD}$ and the number of patients with A. actinomycetemcomitans due to the adjunctive use of FQ, a finding that contrasted with the control data (Fig. 3).

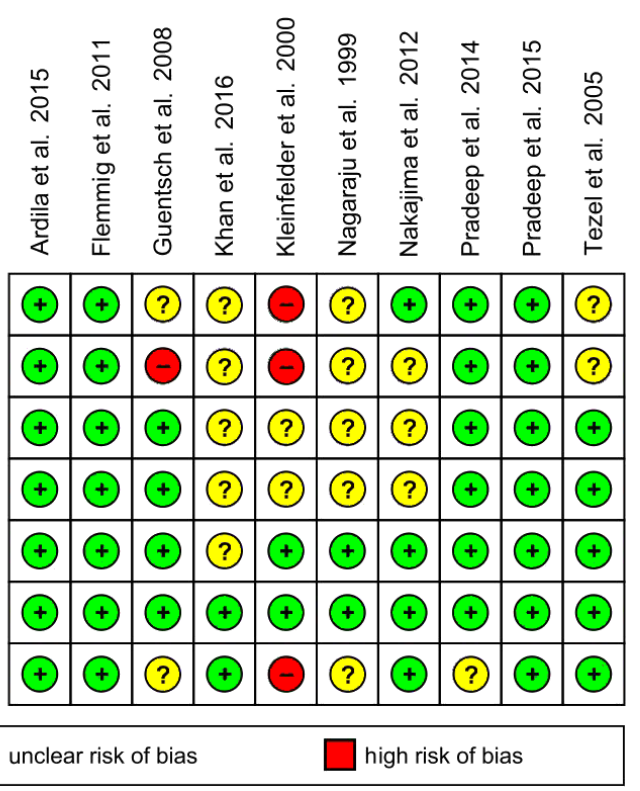


$\Delta \mathrm{PD}$

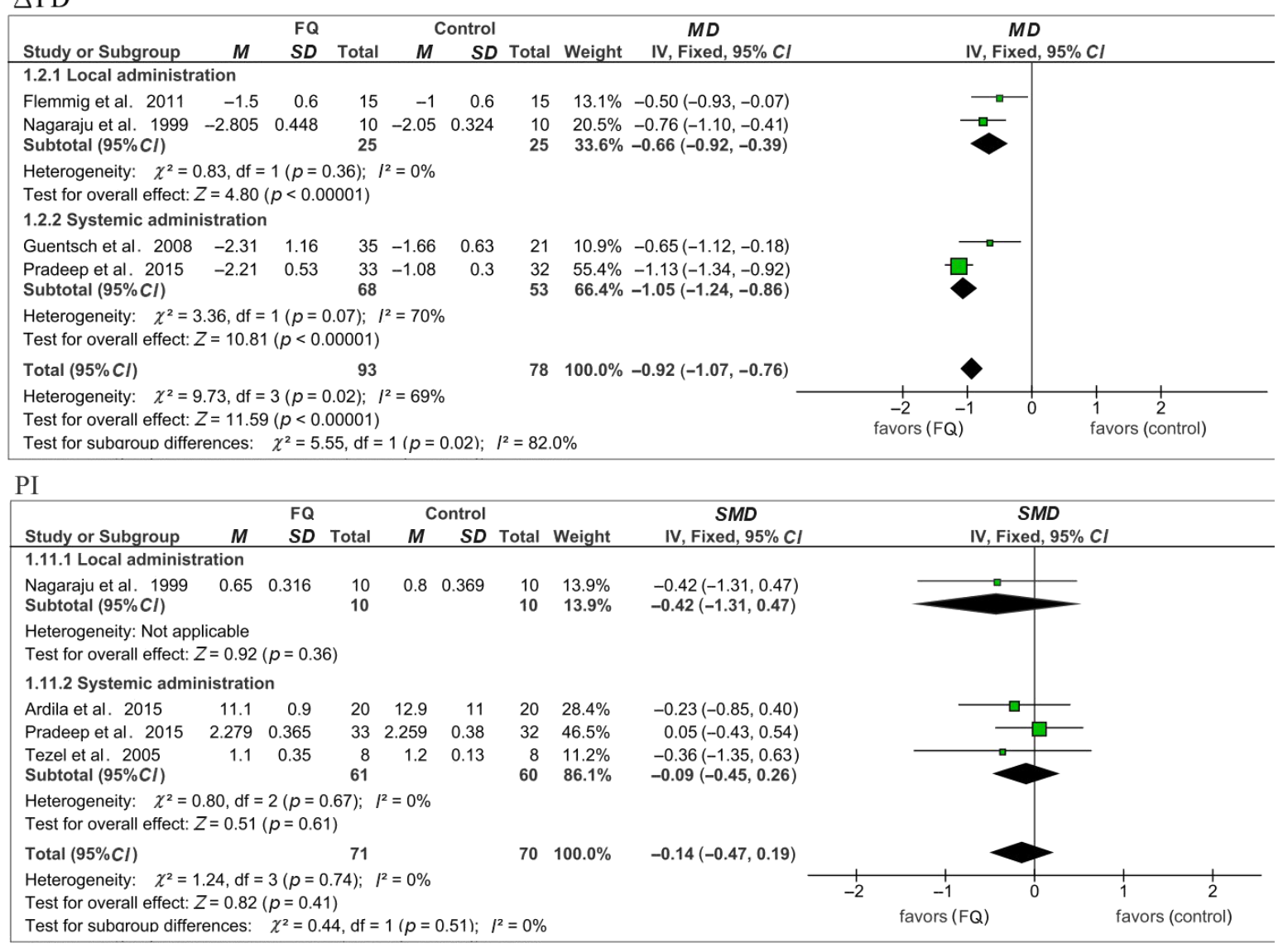

Number of patients with $A a$

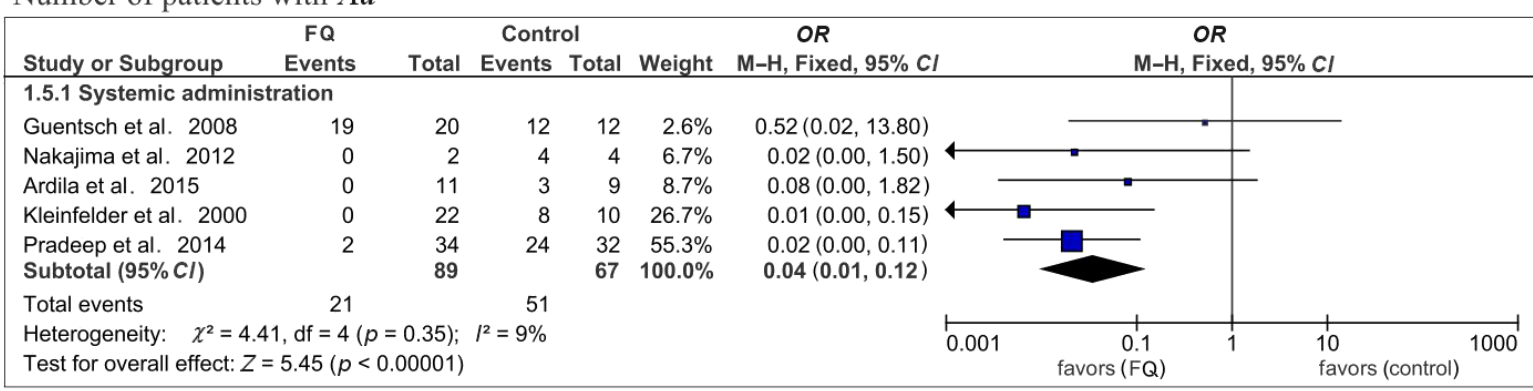

Number of patients with $\mathrm{Pg}$

\begin{tabular}{|c|c|c|c|c|c|c|c|c|c|}
\hline Study or Subgroup & $\begin{array}{c}F Q \\
\text { Events }\end{array}$ & \multicolumn{3}{|c|}{ Control } & Weight & $\begin{array}{c}\text { OR } \\
\text { M-H, Fixed, } 95 \% \mathrm{Cl}\end{array}$ & \multicolumn{3}{|c|}{$\begin{array}{c}\text { OR } \\
\text { M-H, Fixed, } 95 \% \mathrm{Cl}\end{array}$} \\
\hline Guentsch et al. 2008 & 22 & 31 & 14 & 20 & $45.4 \%$ & $1.05(0.31,3.59)$ & & & \\
\hline Total events & 24 & & 21 & & & & & & \\
\hline $\begin{array}{l}\text { Heterogeneity: } \quad \chi^{2}=2 \\
\text { Test for overall effect: }\end{array}$ & $\begin{array}{l}22, \mathrm{df}=1 \\
=1.07(p\end{array}$ & $\begin{array}{l}0.14) ; \\
28)\end{array}$ & $2^{2}=55 \%$ & & & & 0.005 & $\begin{array}{c}0.1 \\
\text { favors }(F Q)\end{array}$ & 10200 \\
\hline
\end{tabular}

Number of patients with $T f$

\begin{tabular}{|c|c|c|c|c|c|c|c|c|c|}
\hline \multicolumn{2}{|c|}{$\begin{array}{lc}\text { Study or Subgroup } & \begin{array}{c}F Q \\
\text { Events }\end{array} \\
\text { 1.7.1 Systemic administration }\end{array}$} & Total & \multicolumn{2}{|c|}{ Control } & Weight & $\begin{array}{c}\text { OR } \\
\text { M-H, Fixed, } 95 \% \mathrm{Cl} \\
\end{array}$ & \multicolumn{2}{|c|}{$\begin{array}{c}\text { OR } \\
\text { M-H, Fixed, } 95 \% \mathrm{Cl}\end{array}$} & \\
\hline Guentsch et al. 2008 & 30 & 33 & 19 & 19 & $40.9 \%$ & $0.22(0.01,4.57)$ & & & \\
\hline Total events & 33 & & 25 & & & & & & \\
\hline $\begin{array}{l}\text { Heterogeneity: } \chi^{2}=0 \\
\text { Test for overall effect: } Z\end{array}$ & $\begin{array}{l}21, \mathrm{df}=1 \\
=1.26(p\end{array}$ & $\begin{array}{l}=0.65) \text {; } \\
21)\end{array}$ & $I^{2}=0 \%$ & & & 0.002 & $\begin{array}{c}0.1 \\
\text { favors (FQ) }\end{array}$ & $\begin{array}{l}10 \\
\text { favors (control) }\end{array}$ & 500 \\
\hline
\end{tabular}

Fig. 3. Periodontal and bacteriological parameters obtained at $\leq 3$ months after the fluoroquinolone (FQ) intervention in patients subjected to a conventional therapy $M$ - mean; SD - standard deviation; $M D$ - mean difference; $S M D$ - standardized mean difference; $C l$ - confidence interval; $\mathrm{df}$ - degrees of freedom; $O R$ - odds ratio; $\mathrm{M}-\mathrm{H}$ - Mantel-Haenszel method. 

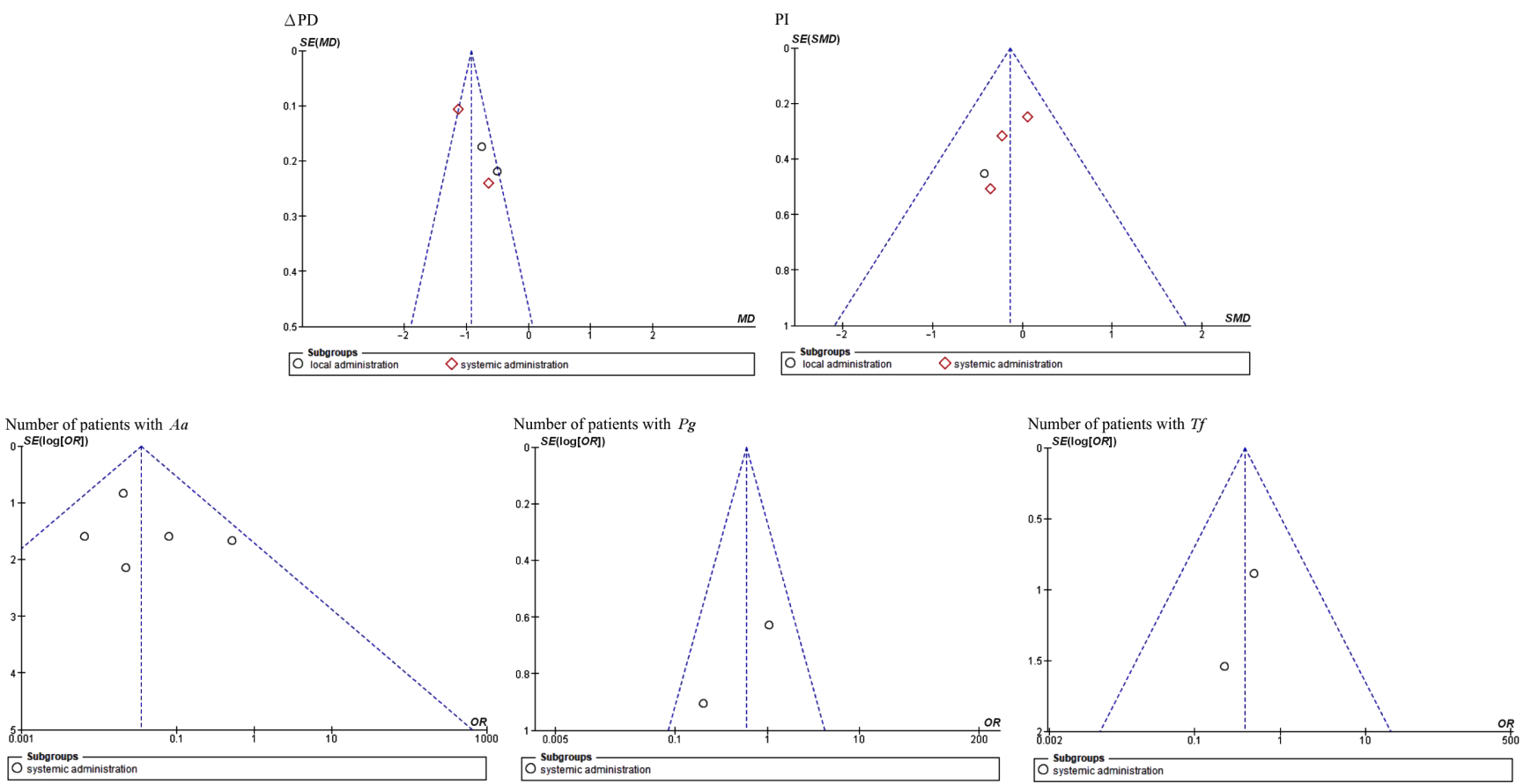

Fig. 4. Funnel plots of meta-analyses at $\leq 3$ months after adjunctive fluoroquinolone (FQ) use in patients subjected to a conventional therapy SE - standard error

Table 3. Additional meta-analyses of the periodontal and microbiological parameters obtained with adjunctive fluoroquinolone (FQ) use

\begin{tabular}{|c|c|c|c|c|c|c|c|}
\hline $\begin{array}{c}\text { Time } \\
\text { [months] }\end{array}$ & Parameter & $\begin{array}{l}\text { Number } \\
\text { of studies }\end{array}$ & Total $95 \% \mathrm{Cl}$ & $\begin{array}{c}\text { Total Z-value } \\
\text { (p-value) }\end{array}$ & $\begin{array}{l}\text { Action in favor } \\
\text { of FQ or control } \\
\text { group }\end{array}$ & $\begin{array}{c}\text { Total } R^{2} \text { statistic } \\
{[\%]} \\
(p \text {-value })\end{array}$ & $\begin{array}{l}\text { Symmetrical } \\
\text { funnel plot }\end{array}$ \\
\hline \multirow{5}{*}{$\leq 3$} & $\triangle C A L$ & $2^{\mathrm{L}}+2^{\mathrm{S}}$ & $-0.94,-0.74$ & $\begin{array}{c}16.35 \\
(<0.00001)\end{array}$ & $\mathrm{FQ}$ & $\begin{array}{c}91 \\
(<0.00001)\end{array}$ & no \\
\hline & CAL & $6^{5}$ & $-0.71,-0.41$ & $\begin{array}{c}7.21 \\
(<0.00001)\end{array}$ & $\mathrm{FQ}$ & $\begin{array}{c}68 \\
(0.008)\end{array}$ & no \\
\hline & PD & $5^{5}$ & $-0.66,-0.32$ & $\begin{array}{c}5.75 \\
(<0.00001)\end{array}$ & $\mathrm{FQ}$ & $\begin{array}{c}84 \\
(<0.00001)\end{array}$ & no \\
\hline & \%BOP & $4^{5}$ & $-3.67,-3.04$ & $\begin{array}{c}21.04 \\
(<0.00001)\end{array}$ & $\mathrm{FQ}$ & $\begin{array}{c}71 \\
(0.02)\end{array}$ & no \\
\hline & Gl & $1^{L}+2^{S}$ & $0.12,0.32$ & $\begin{array}{c}4.47 \\
(<0.00001)\end{array}$ & control & $\begin{array}{c}91 \\
(<0.00001)\end{array}$ & no \\
\hline \multirow{9}{*}{$>3$ and $\leq 6$} & $\% \mathrm{BOP}$ & $3^{5}$ & $-1.12,-0.49$ & $\begin{array}{c}5.02 \\
(<0.00001)\end{array}$ & $\mathrm{FQ}$ & $\begin{array}{c}0 \\
(0.97)\end{array}$ & yes \\
\hline & PI & $2^{s}$ & $-0.46,0.31$ & $\begin{array}{c}0.38 \\
(0.70)\end{array}$ & none & $\begin{array}{c}32 \\
(0.22)\end{array}$ & yes \\
\hline & $A a^{\#}$ & $3^{5}$ & $0.01,0.12$ & $\begin{array}{c}5.38 \\
(<0.00001)\end{array}$ & $\mathrm{FQ}$ & $\begin{array}{c}18 \\
(0.30)\end{array}$ & yes \\
\hline & $P g^{\#}$ & $2^{s}$ & $0.19,1.36$ & $\begin{array}{c}1.34 \\
(0.18)\end{array}$ & none & $\begin{array}{c}18 \\
(0.27)\end{array}$ & yes \\
\hline & $T f^{f}$ & $2^{5}$ & $0.05,0.98$ & $\begin{array}{l}1.98 \\
(0.05)\end{array}$ & none & $\begin{array}{c}0 \\
(0.41)\end{array}$ & yes \\
\hline & $\triangle \mathrm{CAL}$ & $2^{5}$ & $-1.12,-0.70$ & $\begin{array}{c}8.55 \\
(<0.00001)\end{array}$ & $\mathrm{FQ}$ & $\begin{array}{c}92 \\
(0.0003)\end{array}$ & no \\
\hline & CAL & $3^{5}$ & $-0.91,-0.05$ & $\begin{array}{c}6.77 \\
(<0.00001)\end{array}$ & $\mathrm{FQ}$ & $\begin{array}{c}89 \\
(<0.00001)\end{array}$ & no \\
\hline & $\triangle P D$ & $2^{s}$ & $-1.39,-0.98$ & $\begin{array}{c}11.19 \\
(<0.00001)\end{array}$ & $\mathrm{FQ}$ & $\begin{array}{c}82 \\
(0.02)\end{array}$ & no \\
\hline & PD & $3^{5}$ & $-0.64,-0.33$ & $\begin{array}{c}6.22 \\
(<0.00001)\end{array}$ & $\mathrm{FQ}$ & $\begin{array}{c}93 \\
(<0.00001)\end{array}$ & no \\
\hline \multirow{4}{*}{$>6$ and $\leq 12$} & $A a^{\#}$ & $2^{5}$ & $0.00,0.22$ & $\begin{array}{c}3.29 \\
(0.001)\end{array}$ & $\mathrm{FQ}$ & $\begin{array}{c}0 \\
(0.33)\end{array}$ & yes \\
\hline & $\% B O P$ & $2^{5}$ & $0.38,7.78$ & $\begin{array}{l}2.16 \\
(0.03)\end{array}$ & control & $\begin{array}{c}33 \\
(0.22)\end{array}$ & yes \\
\hline & CAL & $2^{5}$ & $-0.37,0.21$ & $\begin{array}{c}0.52 \\
(0.60)\end{array}$ & none & $\begin{array}{c}44 \\
(0.18)\end{array}$ & yes \\
\hline & PD & $2^{5}$ & $-0.34,0.10$ & $\begin{array}{l}1.05 \\
(0.29)\end{array}$ & none & $\begin{array}{c}0 \\
(0.74)\end{array}$ & yes \\
\hline
\end{tabular}

LFQ agents administered locally; ${ }^{5} \mathrm{FQ}$ agents administered systemically; ${ }^{\sharp}$ number of patients with a pathogen. 
At $>3$ and $\leq 6$ months post-intervention, the $95 \% C I$, $Z$-values and $p$-values obtained in the meta-analyses showed a reduction in the \%BOP and the number of patients with A. actinomycetemcomitans due to the adjunctive use of FQ, a finding that contrasted with the control group (Table 3). On the other hand, the PI values and the number of subjects with $P$. gingivalis and $T$. forsythia were not modified by FQ agents (Table 3). All the foregoing analyses found the absence of heterogeneity and reporting bias (Table 3 ). While the meta-analyses of $\triangle \mathrm{CAL}, \mathrm{CAL}, \triangle \mathrm{PD}$, and PD showed statistical changes in their $Z$-values, these results presented with considerable heterogeneity and reporting bias (Table 3 ).

At $>6$ and $\leq 12$ months post-intervention, the $95 \% C I$, $Z$-values and $p$-values obtained in the meta-analyses showed a reduction in the number of patients with detectable $A$. actinomycetemcomitans due to the use of FQ agents as adjuncts to a conventional therapy, a finding that contrasted with the control group (Table 3). During this period, the control group exhibited reduced \%BOP, in contrast with the test group, while the meta-analyses conducted for CAL and PD did not show beneficial changes due to the adjunctive use of FQ. Acceptable heterogeneity and reporting bias were found in these analyses (Table 3).

For the safety evaluation, the overall analysis (95\% CI, $Z$-values and $p$-values) did not show a significant presence of drug-related adverse events due to the use of FQ in patients with periodontitis, in contrast to the control data. The absence of heterogeneity and reporting bias was observed for this analysis (Fig. 5).

\section{Discussion}

To our knowledge, this is the first systematic review and meta-analysis that has evaluated the beneficial and harmful effects of the use of FQ agents as adjuncts to a conventional therapy for patients with periodontitis. The present study included patients diagnosed with chronic, adult or aggressive periodontitis (Table 1). It should be noted that the term 'adult periodontitis' was replaced with 'chronic periodontitis' in 1999 to avoid a diagnostic dilemma for clinicians. ${ }^{52}$ Previously, authors either classified periodontal disease in accordance with the American Academy of Periodontology's 1999 classification system $^{3,14,17,19,51}$ or reported the diagnosis of the disease without any description of the classification system used. ${ }^{16,18,20,22-24,26}$ While we confirmed the classification of periodontal disease used in each study selected for the present paper, ${ }^{1,52}$ we could not support the diagnosis of the disease in 3 studies due to the limited information presented on the classification used. ${ }^{16,22,24}$ The review presented here analyzed aggressive and chronic periodontitis together, given that the updated guidance on the management of periodontitis proposes that they be combined as a single entity, despite having different phenotypes. ${ }^{1}$ The meta-analysis included only 1 study conducted on patients with aggressive periodontitis. ${ }^{14}$
All of the studies included in the meta-analyses examined either locally or systemically administered CPX, LVX, MOX, SPX, STX, or OFX in combination with conventional treatment for periodontitis (Table 1). Our literature search found 2 previous reviews and meta-analyses in this area, including more than 25 studies. ${ }^{53,54}$ Both these works compared the efficacy of systemic antibiotics combined with scaling and root planing (SRP) with the use of SRP alone. Each meta-analysis included only 1 study that tested the use of $\mathrm{MOX},{ }^{20}$ while the remainder of the analyzed studies used doxycycline, amoxicillin/ metronidazole, metronidazole, azithromycin, clarithromycin, tetracyclines, amoxicillin plus clavulanic acid, ornidazole, or spiramycin in their test groups. ${ }^{53,54}$ The combined use of CPX with metronidazole was mentioned in a previous extensive review that evaluated the effects of adjunctive antimicrobial therapies on A. actinomycetemcomitansassociated periodontitis. ${ }^{55}$ The remaining reviews and meta-analyses evaluating the effects of antibiotics in patients with periodontitis did not include studies that used FQ in their test groups. ${ }^{56-60}$ Our study focused on FQ agents, since other types of antibiotics have already been extensively analyzed, as mentioned above. Moreover, the subgroup or independent analysis should be performed separately for each class of antibiotics in order to correctly evaluate the data from the application of meta-analysis methodologies. ${ }^{61}$

As $P$. gingivalis, $T$. forsythia and other bacteria compose the subgingival plaque biofilm, their microbial communities can negatively affect host immunity in the oral cavity. ${ }^{62}$ Porphyromonas gingivalis is known to be the key pathogen underlying the pathogenesis of chronic periodontitis, ${ }^{63}$ while $A$. actinomycetemcomitans plays a crucial role in the etiology of aggressive periodontitis, and is also associated with the etiology of chronic periodontitis. ${ }^{17,64}$ Furthermore, very few clinical cases of aggressive periodontitis have been associated with the presence of $P$. gingivalis. ${ }^{65}$ The present study found that systemic FQ use as an adjunct to a conventional therapy reduced the number of patients with positive $A$. actinomycetemcomitans detection in the subgingival plaque for up to 12 months post-intervention (Table 2, Table 3 and Fig. 3). This microbiological benefit of the use of FQ agents results from their greater distribution in the gingival crevicular fluid as compared to other antibiotics, their strong antibacterial activity against A. actinomycetemcomitans, and their robust inhibitory effect on the early and mature phases of biofilm formation of A. actinomycetemcomitans. 3,9,14,66 The present study did not find evidence of a reduction in the number of patients with subgingival detection of $P$. gingivalis and $T$. forsythia for up to 6 months after a systemic FQ intervention (Table 3 and Fig. 3). A previous study conducted on patients with chronic periodontitis showed that $P$. gingivalis isolates had low susceptibility to CPX as compared to other antibiotics, such as doxycycline, amoxicillin/clavulanic acid 
and azithromycin. ${ }^{67}$ However, a study conducted on patients with generalized aggressive periodontitis showed that P. gingivalis and T. forsythia isolates were greatly susceptible to MOX. ${ }^{68}$ The above-mentioned in vitro susceptibility tests do not accurately reflect the clinical efficacy of antibiotics and the strains can present different resistance profiles in different geographical areas, depending on the local use and abuse of antimicrobials. ${ }^{68}$ While resistance against MOX in the isolates of periodontal bacteria from patients is yet to be reported, eventually, MOX may be found to be ineffective due to its structural similarity to CPX. ${ }^{11}$ The present study quantitatively analyzed the information pertaining to A. actinomycetemcomitans, $P$. gingivalis and T. forsythia, as these periodontopathogens are strongly associated with the clinical parameters of periodontal disease. Moreover, these bacteria

\section{Adverse events}

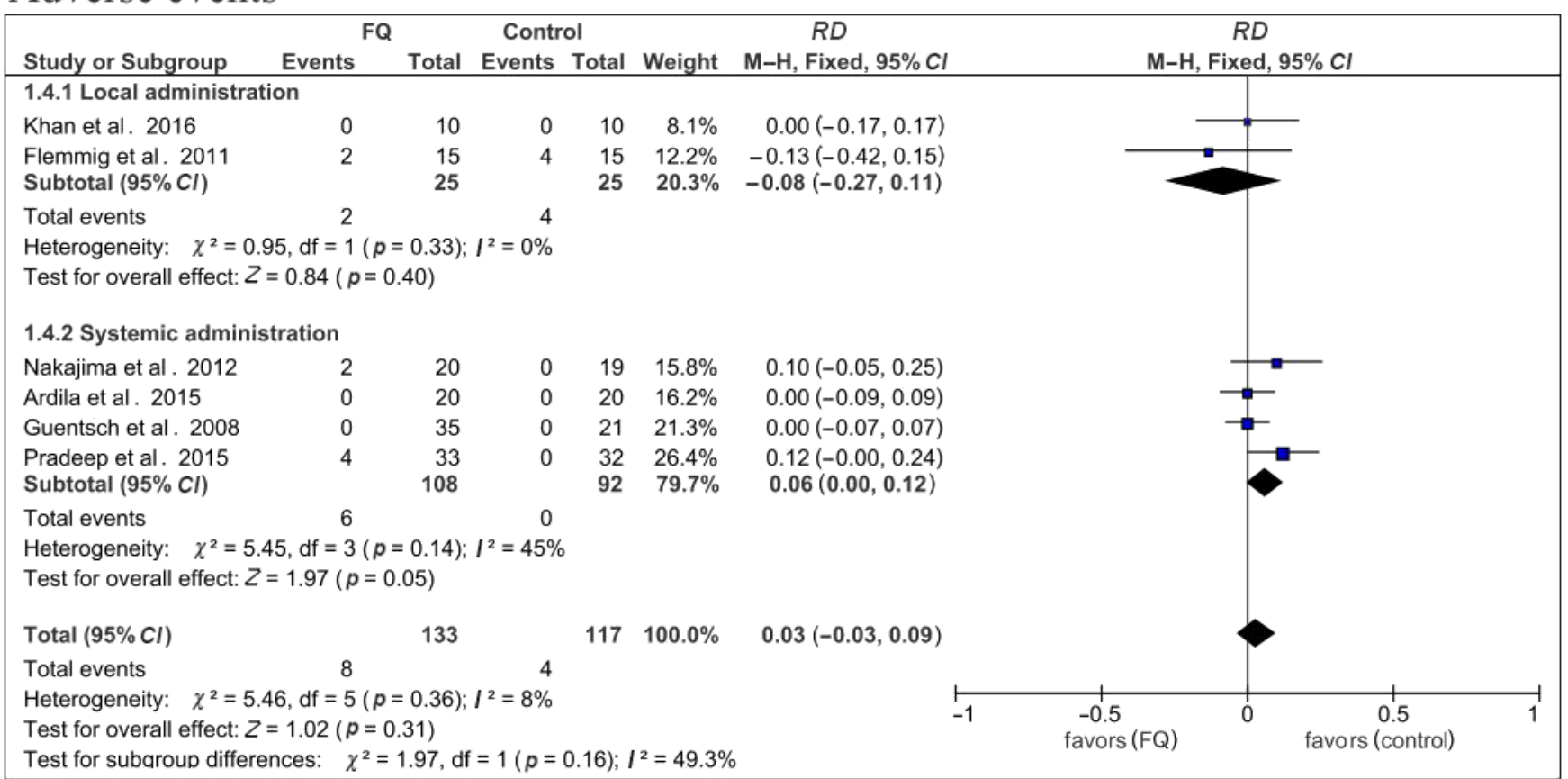

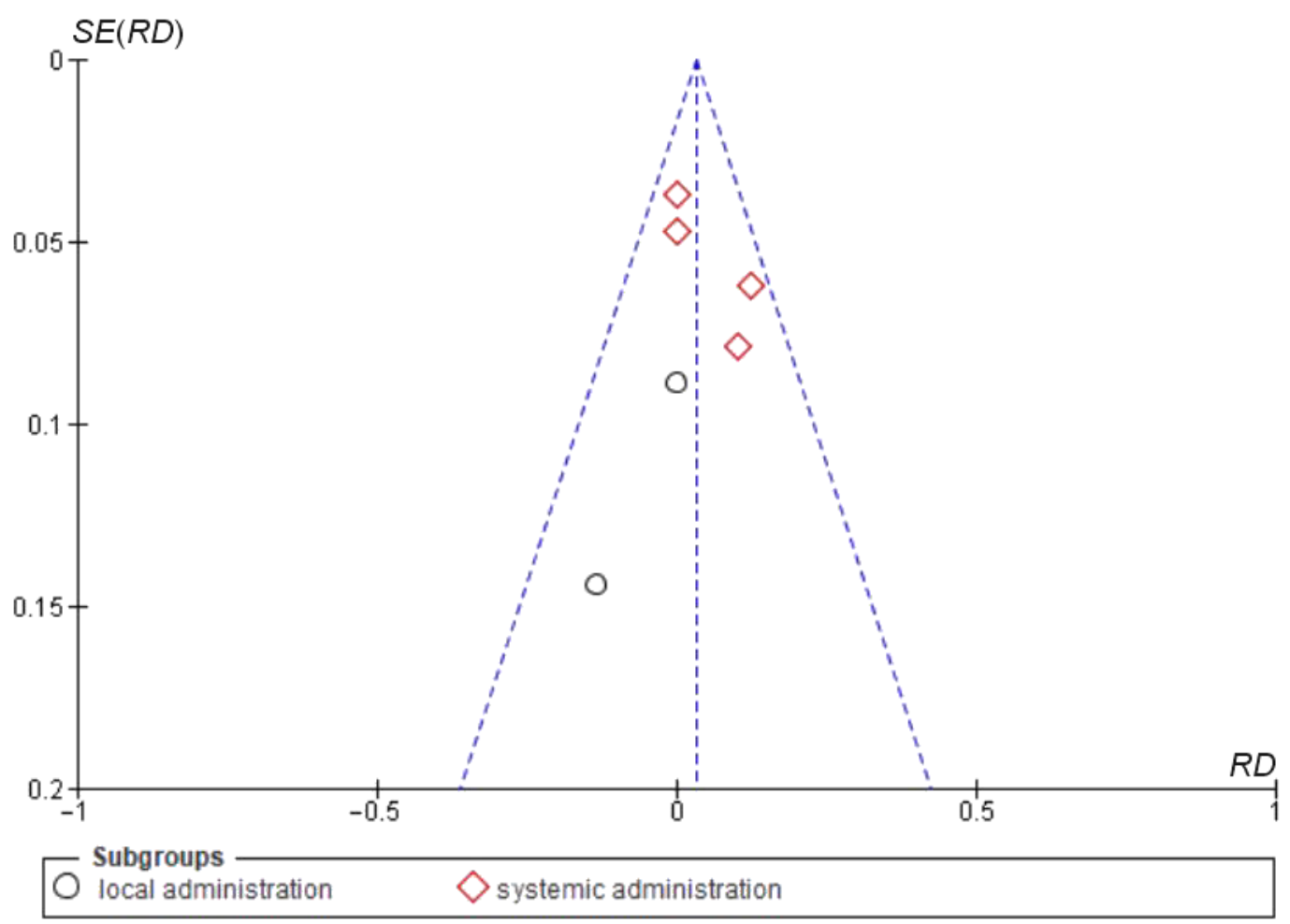

Fig. 5. Meta-analysis and funnel plot of the adverse events caused by the adjunctive use of fluoroquinolone $(F Q)$ agents in patients with periodontitis $R D$ - risk difference. 
are predictors of the treatment outcome $\mathrm{e}^{14}$ and sufficient data was extracted to enable the corresponding analyses.

It is well known that PD is a useful overall indicator of the state of periodontal pockets, while \%BOP reflects the current status of periodontal inflammation and CAL reflects the accumulative periodontal damage. ${ }^{69}$ The present study showed that the levels of $\triangle \mathrm{PD}$ and \%BOP improved at $\leq 3$ months and at $>3$ and $\leq 6$ months after local/systemic or systemic FQ use, respectively (Table 3 and Fig. 3). However, the \%BOP, CAL and PD results did not show beneficial changes for patients after 6 months of a systemic FQ intervention (Table 3). The improvement observed in the periodontal parameters was a consequence of 2 mechanisms exerted by FQ agents. Firstly, the antibacterial activity of FQ reduced the inflammatory response of the host due to a reduction in the level of periodontopathogens observed in pockets. ${ }^{4}$ Secondly, the direct modulation by FQ of the toll-like receptor 4-myeloid differentiation protein-2/nuclear factor- $\kappa B$ signaling reduced the synthesis and release of pro-inflammatory cytokines in immune cells. ${ }^{8,70}$ It should be noted that Table 3 shows that a control therapy had a more beneficial effect on \%BOP at $>6$ months than an FQ intervention. This estimate was made based on the data extracted from the study by Kleinfelder et al., whose baseline examination presented a higher level of \%BOP in the test group than in the control group. ${ }^{23}$ Therefore, a control intervention was more effective, despite a similar level of change in the baseline \%BOP for both groups. ${ }^{23}$

The PI values were recorded in 7 out of the 12 selected studies (Table 2), as dental plaque plays an important role in the development and progression of gingival inflammation. ${ }^{71}$ The present study found that the adjunctive administration of FQ agents did not change supragingival plaque levels for up to 6 months (Table 3 and Fig. 3). This was observed despite the antibacterial effect of FQ agents against bacteria that colonize the supragingival plaque biofilm, such as Streptococcus mitis (S. mitis), Streptococcus oralis (S. oralis) and Streptococcus mutans (S. mutans), their inhibitory action against the biofilm formation of S. mutans $s^{62,72,73}$ and their extensive penetration into saliva after their systemic administration. ${ }^{74}$ It should be noted that adequate oral hygiene routine, the use of mouth rinse and supragingival teeth cleaning (STC), which can contribute to disrupting supragingival plaque, were used in both the test and control groups in some of the studies analyzed in the present paper. ${ }^{71,75-77}$

The present study also found that the adjunctive use of FQ agents exhibited an acceptable safety profile in patients with periodontitis, as these antibiotics did not produce a significant change in the number of adverse events as compared to the control group (Fig. 5). Dizziness, diarrhea and light-headedness were reported in patients receiving a systemic FQ intervention in 3 of the selected studies, ${ }^{3,17,18}$ while gastrointestinal system disorders and resistance mechanism disorders were observed in both the local FQ and placebo therapy groups in 1 study analyzed here. ${ }^{19}$ On the other hand, 3 studies reported the absence of adverse events in patients subjected to both local or systemic drug delivery (Table 2). ${ }^{14,16,20}$ As the widespread use of antibiotics should not be promoted in dental practice, ${ }^{60}$ dental care professionals must balance the clinical benefits against the adverse effects of FQ use, and consider the potential development of both microbial resistance to antibiotics and gut dysbiosis in patients. This latter condition can produce dysbiosis-related systemic diseases, such as increased susceptibility to infectious diseases, altered immune homeostasis, allergic diseases, and metabolic syndrome. ${ }^{78,79}$ As resistance to FQ agents is mediated by a reduction in the number of porins and reduced accumulation of the drug in the bacteria, ${ }^{80}$ the induction of resistant bacterial mutants is rapidly promoted by exposure to low FQ concentrations. The spontaneous mutation rate also contributes to drug resistance via the strain- and quinolone-dependent mechanism. The mechanism of resistance to FQ agents comprises a single amino acid mutation, which leads to a Ser83 $\rightarrow$ Phe substitution in DNA gyrase. ${ }^{11}$ In addition, the administration of FQ agents exposes the subject to a high risk of developing gut dysbiosis. ${ }^{78}$ Since the protection of the gut microbiome during antibiotic therapies should be a priority for the dental care professional, the use of probiotics, such as Saccharomyces boulardii or Lactobacillus rhamnosus GG, can help to prevent gut dysbiosis. These probiotics compete with bacterial pathogens for attachment sites on intestinal cells, and then may exert their biological effects, including the modulation of the content of the gut microbiota and the immune response. ${ }^{78}$ Due to the beneficial health effects of probiotics, treatment with probiotics should be started as soon as possible after the commencement of FQ treatment.

We found $66.7 \%$ and $33.3 \%$ of the studies selected for the present study to be classified as high- and low-quality research, respectively, and acceptable levels of heterogeneity and reporting bias were found. All of the analyzed studies were categorized with a low $(65.7 \%)$, unclear $(28.6 \%)$ or high (5.7\%) risk of bias (Table 3, Fig. 2, Fig. 3, and Fig. 4). All said, the analyses found evidence that FQ can be used safely to improve clinical and microbiological parameters in periodontitis patients receiving a conventional therapy. The outcomes reported in the present study are similar to the beneficial health effects produced by the systemic or local application of other antibiotics (amoxicillin, clavulanic acid, metronidazole, azithromycin, clarithromycin, doxycycline, tetracycline, or chlorhexidine) in diabetic patients with periodontitis, smokers with chronic periodontitis or subjects with aggressive periodontitis. ${ }^{57-60}$ Additionally, our results are in agreement with a recent consensus report on the use of adjunctive antibiotics with SRP in patients diagnosed with periodontitis. ${ }^{56}$ Given the previous absence of a review and meta-analysis of data taken from studies that used FQ combined with 
a conventional therapy, the report recommended the sensible and restricted administration of a combination of amoxicillin and metronidazole, metronidazole alone or azithromycin in patients with periodontitis. ${ }^{56}$

The remainder of our analyses mostly showed that for up to 6 months post-intervention, FQ agents exerted more beneficial effects on the periodontal parameters as compared to controls (Table 3). However, as the metaanalyses conducted in the present study showed high levels of heterogeneity and reporting bias, these results should not be taken into consideration. ${ }^{81}$ Our study shows that there is an urgent need for further high-quality studies with a low risk of bias to add to the currently available evidence in this clinical context. The main limitation of our study was the small number of studies included in some of the meta-analyses undertaken, which may have impacted the interpretation of the results. Nevertheless, the use of the available data for appropriate statistical analyses is essential to support the effective dental, medical and public health decision-making. ${ }^{32}$

\section{Conclusions}

Despite its limitations, the present study showed that the local or systemic administration of $\mathrm{FQ}$ agents produces positive effects on some clinical and microbiological parameters of periodontitis in patients receiving a conventional therapy. These positive effects, which include an improvement in $\triangle \mathrm{PD}$ at $\leq 3$ months, reduced \%BOP at $>3$ and $\leq 6$ months, and a low prevalence of patients with A. actinomycetemcomitans for up to 12 months, are not observed following an antibiotic-free conventional therapy. All of the beneficial effects of FQ agents were observed with an insignificant presence of mild adverse events. The adjunctive use of FQ should be considered only when the expected benefits are greater than the potential adverse clinical consequences, including bacterial resistance, dysbiosis and dysbiosis-related diseases.

\section{Ethical approval}

This study was not performed on human participants or animals.

\section{ORCID iDs}

Saray Aranda Romo (1) https://orcid.org/0000-0002-0379-9626 Flavio Martinez-Morales (1) https://orcid.org/0000-0003-0339-1089 Othoniel Hugo Aragon-Martinez (1) https://orcid.org/0000-0003-2298-404X

\section{References}

1. Kumar S. Evidence-based update on diagnosis and management of gingivitis and periodontitis. Dent Clin North Am. 2019;63(1):69-81. doi:10.1016/j.cden.2018.08.005

2. Gu Y, Han X. Toll-like receptor signaling and immune regulatory lymphocytes in periodontal disease. Int J Mol Sci. 2020;21(9):3329. doi:10.3390/ijms21093329
3. Pradeep AR, Singh SP, Martande SS, et al. Clinical and microbiological effects of levofloxacin in the treatment of chronic periodontitis: A randomized, placebo-controlled clinical trial. J Investig Clin Dent. 2015;6(3):170-178. doi:10.1111/jicd.12091

4. Gasner NS, Schure RS. Periodontal disease. In: StatPearls [Internet]. Treasure Island, USA: StatPearls Publishing; 2021. https://www. ncbi.nlm.nih.gov/books/NBK554590/. Updated March 10, 2021. Accessed August 19, 2020.

5. Gharbi A, Hamila A, Bouguezzi A, et al. Biochemical parameters and oxidative stress markers in Tunisian patients with periodontal disease. BMC Oral Health. 2019;19(1):225. doi:10.1186/s12903-019-0912-4

6. El Tantawi M, AlAgl A. Association between gingivitis severity and lifestyle habits in young Saudi Arabian males. East Mediterr Health J. 2018;24(6):504-511. doi:10.26719/2018.24.6.504

7. McCracken G, Asuni A, Ritchie M, Vernazza C, Heasman P. Failing to meet the goals of periodontal recall programs. What next? Periodontol 2000. 2017;75(1):330-352. doi:10.1111/prd.12159

8. Zusso M, Lunardi V, Franceschini D, et al. Ciprofloxacin and levofloxacin attenuate microglia inflammatory response via TLR4/NF-KB pathway. J Neuroinflammation. 2019;16(1):148. doi:10.1186/s12974-019-1538-9

9. Lavda M, Clausnitzer CE, Walters JD. Distribution of systemic ciprofloxacin and doxycycline to gingiva and gingival crevicular fluid. J Periodontol. 2004;75(12):1663-1667. doi:10.1902/jop.2004.75.12.1663

10. Fluoroquinolones. In: LiverTox: Clinical and Research Information on Drug-Induced Liver Injury [Internet]. Bethesda, USA: National Institute of Diabetes and Digestive and Kidney Diseases; 2012. https:// www.ncbi.nlm.nih.gov/books/NBK547840/. Updated March 10, 2020. Accessed July 30, 2020.

11. Rocha-Roa C, Cossio-Pérez R, Molina D, Patiño J, Cardona N. In silico study of moxifloxacin derivatives with possible antibacterial activity against a resistant form of DNA gyrase from Porphyromonas gingivalis. Arch Oral Biol. 2018;95:30-39. doi:10.1016/j.archoralbio.2018.07.015

12. Idowu T, Schweizer F. Ubiquitous nature of fluoroquinolones: The oscillation between antibacterial and anticancer activities. Antibiotics (Basel). 2017;6(4):26. doi:10.3390/antibiotics6040026

13. Ardila CM, Guzmán IC. Clinical factors influencing the efficacy of systemic moxifloxacin in the therapy of patients with generalized aggressive periodontitis: A multilevel analysis from a clinical trial. Glob J Health Sci. 2015;8(3):80-88. doi:10.5539/gjhs.v8n3p80

14. Ardila CM, Martelo-Cadavid JF, Boderth-Acosta G, Ariza-Garcés AA, Guzmán IC. Adjunctive moxifloxacin in the treatment of generalized aggressive periodontitis patients: Clinical and microbiological results of a randomized, triple-blind and placebo-controlled clinical trial. J Clin Periodontol. 2015;42(2):160-168. doi:10.1111/jcpe.12345

15. Ardila CM, Guzmán IC. Benefits of adjunctive moxifloxacin in generalized aggressive periodontitis: A subgroup analyses in Aggregatibacter actinomycetemcomitans-positive/negative patients from a clinical trial. J Investig Clin Dent. 2017;8(2):e12197. doi:10.1111/jicd.12197

16. Khan G, Yadav SK, Patel RR, Nath G, Bansal M, Mishra B. Development and evaluation of biodegradable chitosan films of metronidazole and levofloxacin for the management of periodontitis. AAPS PharmSciTech. 2016;17:1312-1325. doi:10.1208/s12249-015-0466-y

17. Pradeep AR, Singh SP, Martande SS, et al. Clinical and microbiological effects of levofloxacin in the treatment of Aggregatibacter actinomycetemcomitans-associated periodontitis: A randomized placebo-controlled clinical trial. J Investig Clin Dent. 2015[Epub 2014];6(3):170-178. doi:10.1111/jicd.12091

18. Nakajima T, Okui T, Miyauchi S, et al. Effects of systemic sitafloxacin on periodontal infection control in elderly patients. Gerodontology. 2012;29(2):e1024-e1032.

19. Flemmig TF, Petersilka G, Völp A, et al. Efficacy and safety of adjunctive local moxifloxacin delivery in the treatment of periodontitis. J Periodontol. 2011;82(1):96-105. doi:10.1902/jop.2010.100124

20. Guentsch A, Jentsch H, Pfister W, Hoffmann T, Eick S. Moxifloxacin as an adjunctive antibiotic in the treatment of severe chronic periodontitis. J Periodontol. 2008;79(10):1894-1903. doi:10.1902/jop.2008.070493

21. Guzeldemir-Akcakanat E, Gurgan CA. Systemic moxifloxacin vs amoxicillin/metronidazole adjunct to non-surgical treatment in generalized aggressive periodontitis. Med Oral Patol Oral Cir Bucal. 2015;20(4):e441-e449. doi:10.4317/medoral.20552 
22. Parthasarathy V, Manavalan R, Mythili R, Siby CT, Jeya M. Ethyl cellulose and polyethylene glycol-based sustained-release sparfloxacin chip: An alternative therapy for advanced periodontitis. Drug Dev Ind Pharm. 2002;28(7):849-862. doi:10.1081/ddc-120005631

23. Kleinfelder JW, Mueller RF, Lange DE. Fluoroquinolones in the treatment of Actinobacillus actinomycetemcomitans-associated periodontitis. J Periodontol. 2000;71(2):202-208. doi:10.1902/jop.2000.71.2.202

24. Nagaraju R, Udupa N, Mathew J, Varma BR. Biodegradable dental implants of ciprofloxacin beta-cyclodextrin inclusion complex in the treatment of periodontitis. Indian J Exp Biol. 1999;37(3):305-307.

25. Yamagami H, Takamori A, Sakamoto T, Okada H. Intrapocket chemotherapy in adult periodontitis using a new controlled-release insert containing ofloxacin (PT-01). J Periodontol. 1992;63(1):2-6. doi:10.1902/jop.1992.63.1.2

26. Kimura S, Toda H, Shimabukuro $\mathrm{Y}$, et al. Topical chemotherapy in human periodontitis using a new controlled-release insert containing ofloxacin. I. Microbiological observation. J Periodontal Res. 1991;26(1):33-41. doi:10.1111/j.1600-0765.1991.tb01623.x

27. Green $S$, Higgins JPT, Alderson P, Clarke M, Mulrow CD, Oxman AD. Chapter 1: Introduction. In: Higgins JPT, Green S, eds. Cochrane Handbook for Systematic Reviews of Interventions. Version 5.1.0. Copenhagen, Denmark: The Nordic Cochrane Centre, The Cochrane Collaboration; 2011.

28. Hutton B, Salanti G, Caldwell DM, et al. The PRISMA extension statement for reporting of systematic reviews incorporating network meta-analyses of health care interventions: Checklist and explanations. Ann Intern Med. 2015;162(11):777-784. doi:10.7326/M14-2385

29. Moher D, Liberati A, Tetzlaff J, Altman DG; PRISMA Group. Preferred reporting items for systematic reviews and metaanalyses: The PRISMA statement. PLoS Med. 2009;6(7):e1000097. doi:10.1371/journal.pmed.1000097

30. Jadad AR, Moore RA, Carroll D, et al. Assessing the quality of reports of randomized clinical trials: Is blinding necessary? Control Clin Trials. 1996;17(1):1-12. doi:10.1016/0197-2456(95)00134-4

31. Isiordia-Espinoza MA, Aragon-Martinez OH, Bollogna-Molina RE, Alonso-Castro ÁJ. Infection, alveolar osteitis, and adverse effects using metronidazole in healthy patients undergoing third molar surgery: A meta-analysis. J Maxillofac Oral Surg. 2018;17(2):142-149. doi:10.1007/s12663-017-1031-x

32. Isiordia-Espinoza MA, Aragon-Martinez $\mathrm{OH}$, Martínez-Morales JF, Zapata-Morales JR. Risk of wound infection and safety profile of amoxicillin in healthy patients which required third molar surgery: A systematic review and meta-analysis. $\mathrm{Br} J$ Oral Maxillofac Surg. 2015;53(9):796-804. doi:10.1016/j.bjoms.2015.06.013

33. Isiordia-Espinoza MA, de Jesús Pozos-Guillén A, Aragon-Martinez OH. Analgesic efficacy and safety of single-dose tramadol and nonsteroidal anti-inflammatory drugs in operations on the third molars: A systematic review and meta-analysis. Br J Oral Maxillofac Surg. 2014;52(9):775-783. doi:10.1016/j.bjoms.2014.05.005

34. Review Manager (RevMan). Version 5.3. Copenhagen, Denmark: The Nordic Cochrane Centre, The Cochrane Collaboration; 2014.

35. Higgins JPT, Deeks JJ, Altman DG. Chapter 16: Special topics in statistics. In: Higgins JPT, Green S, eds. Cochrane Handbook for Systematic Reviews of Interventions. Version 5.1.0. Copenhagen, Denamrk The Nordic Cochrane Centre, The Cochrane Collaboration; 2011.

36. Sterne JAC, Sutton AJ, loannidis JPA, et al. Recommendations for examining and interpreting funnel plot asymmetry in metaanalyses of randomised controlled trials. BMJ. 2011;343:d4002. doi:10.1136/bmj.d4002

37. Alamanda M, Denthumdas SK, Wadgave U, et al. Comparative evaluation of ciprofloxacin levels in GCF and plasma of chronic periodontitis patients: Quasi experimental study. J Clin Diagn Res. 2016;10(6):ZC47-ZC50. doi:10.7860/JCDR/2016/18446.7987

38. Nakajima $T$, Okui $\mathrm{T}$, Ito $\mathrm{H}$, et al. Microbiological and clinical effects of sitafloxacin and azithromycin in periodontitis patients receiving supportive periodontal therapy. Antimicrob Agents Chemother. 2016;60(3):1779-1787. doi:10.1128/AAC.02575-15

39. Tomita S, Kasai S, Imamura K, et al. Changes in antimicrobial susceptibility profile and prevalence of quinolone low-sensitive strains in subgingival plaque from acute periodontal lesions after systemic administration of sitafloxacin. Microb Pathog. 2015;79:41-46. doi:10.1016/j.micpath.2015.01.005
40. Tomita S, Kasai S, Ihara Y, et al. Effects of systemic administration of sitafloxacin on subgingival microflora and antimicrobial susceptibility profile in acute periodontal lesions. Microb Pathog. 2014;71-72:1-7. doi:10.1016/j.micpath.2014.04.003

41. Guzmán IC, Romero HG, Ardila Medina CM. Adjunctive systemic administration of moxifloxacin versus ciprofloxacin plus metronidazole in the treatment of chronic periodontitis harboring Gramnegative enteric rods: II. A multilevel analysis. Rev Fac Odontol Univ Antioq. 2012;23(2):207-224.

42. Guzmán Zuluaga IC, Romero HG, Ardila Medina CM. Adjunctive systemic administration of moxifloxacin versus ciprofloxacin plus metronidazole in the treatment of chronic periodontitis harboring gram-negative enteric rods: I. Microbiological and clinical effects. Rev Fac Odontol Univ Antioq. 2011;23(1):92-110.

43. Dannewitz B, Pohl S, Eickholz P, Kim TS. Clinical and microbiological effects of a combined mechanic-antibiotic therapy in subjects with Actinobacillus actinomycetemcomitans-associated periodontitis. Am J Dent. 2007;20(3):153-156.

44. Soleymani Shayesteh Y, Khorsand A, Salary MH, Mehrizy H. Comparison of systemic ciprofloxacin in elimination of A.a from active sites with combination of metronidazole and amoxicillin in patients with aggressive periodontitis: A randomized double blind controlled trial. Front Dent. 2004;1(2):24-28.

45. Tözüm TF, Yildirim A, Cağlayan F, Dinçel A, Bozkurt A. Serum and gingival crevicular fluid levels of ciprofloxacin in patients with periodontitis. J Am Dent Assoc. 2004;135(12):1728-1732. doi:10.14219/jada.archive.2004.0127

46. Conway TB, Beck FM, Walters JD. Gingival fluid ciprofloxacin levels at healthy and inflamed human periodontal sites. J Periodontol. 2000;71(9):1448-1452. doi:10.1902/jop.2000.71.9.1448

47. Müller HP, Heinecke A, Borneff M, Kiencke C, Knopf A, PohI S. Eradication of Actinobacillus actinomycetemcomitans from the oral cavity in adult periodontitis. J Periodontal Res. 1998;33(1):49-58. doi:10.1111/j.1600-0765.1998.tb02291.x

48. Higashi K, Morisaki K, Hayashi S, et al. Local ofloxacin delivery using a controlled-release insert (PT-01) in the human periodontal pocket. JPeriodontal Res. 1990;25(1):1-5. doi:10.1111/j.1600-0765.1990.tb01201.x

49. Ardila Medina CM, Solarte Velasco AS, Guzmán Zuluaga IC. Porphyromonas gingivalis: Influence on the effectiveness of periodontal therapy [in Spanish]. AMC. 2016;20(4):425-431.

50. Kadadasu R, Atchuta A, Palaparthy R, Reddy SH, Sisinty V, Beeravolu M. Clinicomicrobiological evaluation of the efficacy of local delivery of moxifloxacin and ibuprofen gel as an adjunct to scaling and root planing in chronic periodontitis patients. J Oral Maxillofac Pathol. 2020;24(1):26-32. doi:10.4103/jomfp.JOMFP_253_19

51. Tezel A, Yucel O, Orbak R, et al. The gingival crevicular fluid ciprofloxacin level in subjects with gingivitis and periodontitis, and its effects on clinical parameters. J Periodontal Res. 2005;40(5):395-400. doi:10.1111/j.1600-0765.2005.00820.x

52. Armitage GC. Development of a classification system for periodontal diseases and conditions. Ann Periodontol. 1999;4(1):1-6. doi:10.1902/annals.1999.4.1.1

53. Smiley CJ, Tracy SL, Abt E, et al. Systematic review and meta-analysis on the nonsurgical treatment of chronic periodontitis by means of scaling and root planing with or without adjuncts. J Am Dent Assoc. 2015;146(7):508-524.e.5. doi:10.1016/j.adaj.2015.01.028

54. Keestra JAJ, Grosjean I, Coucke W, Quirynen M, Teughels W. Nonsurgical periodontal therapy with systemic antibiotics in patients with untreated chronic periodontitis: A systematic review and metaanalysis. J Periodontal Res. 2015;50(3):294-314. doi:10.1111/jre.12221

55. Jepsen K, Jepsen S. Antibiotics/antimicrobials: Systemic and local administration in the therapy of mild to moderately advanced periodontitis. Periodontol 2000. 2016;71(1):82-112. doi:10.1111/prd.12121

56. Pretzl B, Sälzer S, Ehmke B, et al. Administration of systemic antibiotics during non-surgical periodontal therapy - a consensus report. Clin Oral Investig. 2019;23(7):3073-3085. doi:10.1007/s00784-018-2727-0

57. Souto MLS, Rovai ES, Ganhito JA, Holzhausen M, Chambrone L, Pannuti CM. Efficacy of systemic antibiotics in nonsurgical periodontal therapy for diabetic subjects: A systematic review and meta-analysis. Int Dent J. 2018;68(4):207-220. doi:10.1111/idj.12384 
58. Chambrone L, Vargas M, Arboleda S, et al. Efficacy of local and systemic antimicrobials in the non-surgical treatment of smokers with chronic periodontitis: A systematic review. J Periodontol. 2016;87(11):1320-1332. doi:10.1902/jop.2016.160268

59. Fritoli A, Gonçalves C, Faveri M, et al. The effect of systemic antibiotics administered during the active phase of non-surgical periodontal therapy or after the healing phase: A systematic review. J Appl Oral Sci. 2015;23(3):249-254. doi:10.1590/1678-775720140453

60. Keestra JAJ, Grosjean I, Coucke W, Quirynen M, Teughels W. Nonsurgical periodontal therapy with systemic antibiotics in patients with untreated aggressive periodontitis: A systematic review and metaanalysis. J Periodontal Res. 2015;50(6):689-706. doi:10.1111/jre.12252

61. Aranda Romo S, Martinez-Morales F, Zapata-Morales JR, Aragon-Martinez $\mathrm{OH}$. Interpretation of data: Does amoxicillin reduce the risk of infection in patients after third molar extraction? Int J Oral Maxillofac Surg. 2020;49(6):836-837. doi:10.1016/j.ijom.2019.08.023

62. Digel I, Kern I, Geenen EM, Akimbekov N. Dental plaque removal by ultrasonic toothbrushes. Dent J (Basel). 2020;8(1):28. doi:10.3390/dj8010028

63. Jia L, Han N, Du J, Guo L, Luo Z, Liu Y. Pathogenesis of important virulence factors of Porphyromonas gingivalis via toll-like receptors. Front Cell Infect Microbiol. 2019;9:262. doi:10.3389/fcimb.2019.00262

64. Velusamy SK, Sampathkumar V, Ramasubbu N, Paster BJ, Fine DH. Aggregatibacter actinomycetemcomitans colonization and persistence in a primate model. Proc Natl Acad Sci U S A. 2019;116(44):22307-22313. doi:10.1073/pnas.1905238116

65. Ruiz MA, Burguera LG, Rodríguez A. Aggressive periodontitis caused by Porphyromonas gingivales. Report of a case [in Spanish]. MedULA. 2003;12(1-4):36-43.

66. Takahashi N, Ishihara K, Kato T, Okuda K. Susceptibility of Actinobacillus actinomycetemcomitans to six antibiotics decreases as biofilm matures. J Antimicrob Chemother. 2007;59(1):59-65. doi:10.1093/jac/dkl452

67. Japoni A, Vasin A, Noushadi S, Kiany F, Japoni S, Alborzi A. Antibacterial susceptibility patterns of Porphyromonas gingivalis isolated from chronic periodontitis patients. Med Oral Patol Oral Cir Bucal. 2011;16(7):e1031-e1035. doi:10.4317/medoral.17174

68. Ardila CM, Bedoya-García JA. Antimicrobial resistance of Aggregatibacter actinomycetemcomitans, Porphyromonas gingivalis and Tannerella forsythia in periodontitis patients. J Glob Antimicrob Resist. 2020;22:215-218. doi:10.1016/j.jgar.2020.02.024

69. Pei XY, He L, Ouyang XY. Proposing a novel, three-level definition of periodontitis using probing depth, clinical attachment loss and bleeding on probing: Analysis of a rural Chinese population. Chin J Dent Res. 2017;20(2):89-96. doi:10.3290/j.cjdr.a38273

70. Dalhoff A. Immunomodulatory activities of fluoroquinolones. Infection. 2005;33 Suppl 2:55-70. doi:10.1007/s15010-005-8209-8

71. Lin J, Dinis M, Tseng CH, et al. Effectiveness of the GumChucks flossing system compared to string floss for interdental plaque removal in children: A randomized clinical trial. Sci Rep. 2020;10(1):3052. doi:10.1038/s41598-020-59705-w

72. Saputo S, Faustoferri RC, Quivey RG Jr. A drug repositioning approach reveals that Streptococcus mutans is susceptible to a diverse range of established antimicrobials and nonantibiotics. Antimicrob Agents Chemother. 2017;62(1):e01674-17. doi:10.1128/AAC.01674-17

73. Nakajima T, Nakanishi S, Mason C, et al. Population structure and characterization of viridans group streptococci (VGS) isolated from the upper respiratory tract of patients in the community. Ulster Med J. 2013;82(3):164-168.

74. Li Q, Naora K, Hirano H, Okunishi H, Iwamoto K. Comparative study on salivary distribution of fluoroquinolones in rats. Biol Pharm Bull. 2002;25(8):1084-1089. doi:10.1248/bpb.25.1084

75. Dehghani M, Abtahi M, Hasanzadeh N, Farahzad Z, Noori M, Noori M. Effect of Propolis mouthwash on plaque and gingival indices over fixed orthodontic patients. J Clin Exp Dent. 2019;11(3):e244-e249. doi:10.4317/jced.55026

76. Moeintaghavi A, Sargolzaie N, Rostampour M, Sarvari S, Kargozar S, Gharaei S. Comparison of three types of tooth brushes on plaque and gingival indices: A randomized clinical trial. Open Dent J. 2017;11:126-132. doi:10.2174/1874210601711010126

77. Wang PL. Roles of oral bacteria in cardiovascular diseases - from molecular mechanisms to clinical cases: Treatment of periodontal disease regarded as biofilm infection: Systemic administration of azithromycin. J Pharmacol Sci. 2010;113(2):126-133. doi:10.1254/jphs.09r25fm
78. Aragon-Martinez OH, Martinez-Morales F, Bologna Molina R, Aranda Romo S. Should dental care professionals prescribe probiotics for their patients under antibiotic administration? Int Dent J. 2019;69(5):331-333. doi:10.1111/idj.12459

79. Aragon-Martinez $\mathrm{OH}$, Isiordia-Espinoza MA, Tejeda Nava FJ, Aranda Romo S. Dental care professionals should avoid the administration of amoxicillin in healthy patients during third molar surgery: Is antibiotic resistance the only problem? J Oral Maxillofac Surg. 2016;74(8):1512-1513. doi:10.1016/j.joms.2016.04.026

80. Eick S, Schmitt A, Sachse S, Schmidt KH, Pfister W. In vitro antibacterial activity of fluoroquinolones against Porphyromonas gingivalis strains. J Antimicrob Chemother. 2004;54(2):553-556. doi:10.1093/jac/dkh354

81. Deeks JJ, Higgins JPT, Altman DG, eds. Chapter 9: Analysing data and undertaking meta-analyses. In: Higgins JPT, Green S, eds. Cochrane Handbook for Systematic Reviews of Interventions. Version 5.1.0 (updated March 2011). Copenhagen, Denmark: The Nordic Cochrane Centre, The Cochrane Collaboration, 2011. Available from www.handbook.cochrane.org. 